\title{
Imágenes de la caridad catedralicia. Orígenes y evolución funcional de las pinturas de la Pia Almoina de Lleida*
}

\author{
Gloria Fernández Somoza \\ Universitat Autónoma de Barcelona
}

\begin{abstract}
RESUMEN. Las pinturas murales del refectorio de la Pia Almoina, en la Catedral de Lleida, presentan un abanico pictórico que va desde el siglo XIV hasta el XVI, siendo durante todo este tiempo un fiel reflejo de la funcionalidad del espacio, y mostrándonos además su utilidad en la práctica caritativa. Estamos pues ante uno de esos pocos ejemplos medievales que hemos conservado en los que las artes figurativas y el espacio arquitectónico que ornan se unen en un todo para testimoniar una realidad cotidiana.

Palabras clave: Catedral de Lleida, Pia Almoina, refectorio, pinturas, gótico, iconografía.

ABSTRACT. The wall-paintings from the Almonry refectory -the so-called Pia Almoina- of the Cathedral of Lleida display a pictorial succession that goes from $14^{\text {th }}$ to $16^{\text {th }}$ century. These paintings are a faithful reflection of the functionality of the architectonic space, and show in addition its actually charitable utility during the Middle Ages. We are then before one of those few medieval examples that we have preserved in that the wall-paintings and their architectonic space are a whole to attest a daily reality.

Key Words: Cathedral of Lleida. Almonry. Refectory. Medieval Wall-painting. Gothic. Iconography.
\end{abstract}

En 1947 comenzaron los trabajos de restauración en la Seu Vella de Lleida que, dirigidos por el arquitecto A. Ferrant y el aparejador J. Benavent, tuvieron como fruto, entre otros muchos, el descubrimiento de las pinturas murales que decoraron las paredes del edificio destinado a Pia Almoina

*Quisiera expresar aquí mi agradecimiento a Francesc Fité y Carmen Berlabé porque, en primer lugar, ellos fueron los incitadores de este trabajo hace ya algún tiempo $\mathrm{y}$, en segundo, me facilitaron la entrada a archivos y museos en un inolvidable, aunque tórrido, verano ilerdense. o limosna pía de la catedral ${ }^{1}$. Fueron enton-

\footnotetext{
-

${ }^{1}$ Siendo estrictos, habría que hablar de redescubrimiento ya que, según J. Ainaud se tenía conocimiento previo de la existencia de las pinturas (J. AINAUD DE LASARTE, "La historia de las pinturas de la Seu Vella", La Mañana, 29 de mayo, 1979, pp. 5-7, en especial p. 5; J. LladonOSA PUjOL, "Dependencias y anejos de la Seo Antigua", Ciudad, 1956, pp. 83-84, en concreto p. 84; J. SUREDA i PONS, “Decoració mural del refectori de la Seu Vella de Lleida", Thesaurus / Estudis. L'Art als Bisbats de Catalunya, Barcelona, 1986, no 64, pp. 108-109, en especial p. 108). En cuanto al trabajo realizado por A. Ferrant en la catedral de Lleida tenemos como prueba testimonial las memorias de restauración en las que fundamentalmente, y como suele ser
} 
ces llevadas a Barcelona para su restauración, con la intención de retornarlas a su emplazamiento originario dentro de la catedral, una vez hubieran terminado las obras de rehabilitación de ésta. Sin embargo, ciertas dificultades impidieron la recuperación de dicha dependencia claustral y su posterior destinación a convento y casa de ejercicios diocesana paralizó la intención de reubicar las pinturas en su lugar originario. Tales razones llevaron a depositar temporalmente los frescos de la Pia Almoina en el Museu d'Art de Catalunya, quedando allí hasta mayo de 1975, momento en el que fueron devueltos a Lleida, pasando a formar parte del fondo artístico del Museu Diocesà $i$ Comarcal, lugar en el que todavía hoy se custodian ${ }^{2}$.

\section{LA 'ALMOINA' DE LLEIDA. UNA INSTITUCIÓN CARITATIVA ME- DIEVAL}

Antes de detenernos en el estudio de las pinturas propiamente dichas es necesario conocer la institución de la Pia Almoina leridana ya que, como veremos en breve, todos los fragmentos pictóricos conservados contienen una misma iconografía, es-

\footnotetext{
ya habitual, se habla de las intervenciones arquitectónicas, con brevísimas e insustanciales alusiones a las pinturas, tanto de la Almoina como del templo catedralicio (A. FERRANT, Obras de restauración en la Antigua Catedral de Lérida, 1955; Id., Obras de restauración en la Iglesia y continuación de la obra de la Casa de Canónigos de la Catedral Antigua de Lérida, 1956, Archivo General de la Administración (Alcalá de Henares) [A.G.A.], sec. Cultura 26/301; Id., Obras de reconstrucción en la Iglesia y continuación de la obra de la casa de canónigos de la Catedral Antigua de Lérida, 1957, A.G.A., sec. Cultura 26/306; Id., Proyecto de obras de conservación de la iglesia y continuación de la casa de ejercicios (de canónigos) de la Antigua Catedral de Lérida, 1959, A.G.A., sec. Cultura 26/342; Id., Restauración de cubiertas del ábside central y parcial de la Casa de Ejercicios de la Antigua Catedral de Lérida, 1960, A.G.A., sec. Cultura 26/150).

2 J. AINAUD DE LASARTE, "La historia de las pinturas de la Seu Vella", op. cit., pp. 5-7.
}

trechamente vinculada a la función de dicha institución, de manera que, para la comprensión del ciclo pictórico y su evolución temporal nos será de sumo interés conocer su historia y desarrollo.

La Pia Almoina fue un establecimiento catedralicio ubicado en el claustro de la Seu Vella de Lleida y que realizaba una labor benéfica, dando alimento a los necesitados ${ }^{3}$. Para ello se contó con la aportación económica de particulares a través de las fundaciones de pobres, además de las rentas catedralicias que se dedicaban a dicha institución ${ }^{4}$. La limosna existió en todas las catedrales hispanas y europeas, dando siempre un tipo de servicio similar al comentado para la Almoina de Lleida, y fundamental para la vida social urbana de toda la Edad Media. El gran éxito de esta institución se debió, en buena parte, a que la mentalidad piadosa de la época contribuyó a la práctica de la caridad, ya que era determinante para el perdón de los pecados, y por tanto para la salvación del alma; práctica ésta para la que fue decisivo el papel jugado por las órdenes mendicantes a partir del siglo $\mathrm{XIII}^{5}$. También desde las propias comunidades catedralicias, ya desde la Tardoantigüedad y la Alta Edad Media se propiciaba la caridad hacia los más necesita-

\footnotetext{
${ }^{3}$ Sobre la institución catedralicia de la Pia Almoina de Lleida véase el monumental y plenamente vigente estudio de P. Sanahuja (Historia de la Beneficencia en Lérida, tomo I, La Almoina de la Catedral, Lleida, 1944) del cual se han extraído buena parte de las noticias que irán apareciendo en las próximas páginas.

${ }^{4}$ En 1346 se reglamentaba la cantidad que pertenecía a los pauperibus claustri ilerdensis ecclesia de los hórreos del Cabildo (A.C.L., Constitutiones Ecclesiae Cathedrali Ilerdensis, cajón 218, fols. 26v. y 27r).

${ }^{5}$ C. BAtlle i Gallart y M. CASAS I NADAL, "La Caritat privada i les institucions benèfiques de Barcelona (segle XIII)", en La pobreza y la Asistencia a los pobres en la Cataluña Medieval, Barcelona, 1980, pp. 117190; C. LóPEZ AlONSO, La pobreza en la España Medieval, Madrid, 1986, pp. 264-291.
} 
dos. En el contexto hispánico, el clero de las sedes episcopales se regía por una serie de estatutos en los que encontramos preceptos isidorianos que regulaban los bienes de la comunidad, destinando parte de ellos a enfermos y pobres (...) eadem pecunia in tribus partibus diuidenda est, quarum erit una pro infirmis et senibus et pro aliquid coemendo in diebus sanctis cultius ad uictum fratribus; alia pro egenis... ${ }^{6}$.

También, la regla eleborada con posterioridad por el santo obispo Crodegango desde la catedral de Metz, dedicaba todo un capítulo a la limosna, calificada como una exigencia primordial de la vida canonical (...) Promde opertet ut praelati Ecclesiae, praecedentium Patrum exempla sectantes, aliquod praeparent receptaculum ubi pauperes colligantur, et de rebus Ecclesiae tantum ibidem depuntent, unde sumptus necessarios iuxta possibilitatem rerum habere valeant ${ }^{7}$. En el Concilio de Aquisgrán de 816 se estableció igualmente que en la iglesia del obispo existiese un lugar de acogida para satisfacer las necesidades de los pobres: Proinde oportet, ut praelati ecclesiae praecedentium Patrum exempla sectantes, aliquod praeparent receptaculum, ubi pauperes colligantur, et de rebus ecclesiae tantum ibidem deputent, unde sumptus necessarios juxta possibilitatem rerum habere valeant, exceptis decimis, quae de ecclesiae villis ibidem conferuntur ${ }^{8}$. Siglos más tarde, en terreno hispano, vuelve a hacerse eco de esta cuestión Alfonso X de Castilla. En sus

\footnotetext{
-

${ }^{6}$ Santos Padres Españoles II. San Leandro, San Isidoro, San Fructuoso. Reglas monásticas de la España visigoda. Los tres libros de la 'Sentencias', Introduc., versión y notas J. Campos Ruíz e I. Roca Melia, Madrid, 1971, p. 119. E. CARRERO SANTAMARÍA, Las construcciones de los cabildos catedralicios en los antiguos Reinos de León y Galicia durante la Edad Media, Tesis Doctoral inédita, Universidad Autónoma de Madrid, 1999, t. I, pp. 6873.

${ }^{7}$ Patrología Latina, ed. J. P. Migne, 221 vols., París, 1844-1864, t. 89, col. 1076.

${ }^{8}$ Ibid., t. 105, cols. 930-931.
}

Siete Partidas, el rey sabio establecía en una de sus leyes que Hospedadores deuen ser los perlados de los pobres. Ca assy lo estableçió la Santa Yglesia, que fuessen las sus casas commo hospitales para reçebirlos en ellas, e darles a comer. E los Apóstoles mismos començaron a fazer esto (...) E, por ende, los Santos Padres touieron por bien que todo quanto sobrasse a los perlados de las rentas de la yglesia, demás de quanto les abondasse a ellos e a sus conpañas, que lo diessen a los pobres (...) E non tan solamente deuen los perlados ser hospedadores, más aún han de fazer limosnas a los que ouieren menester, e mayormente los que son pobres vergonçosos ${ }^{9}$.

Además de estos textos eclesiásticos y jurídicos, hay que tener en cuenta el libro de referencia del cristianismo, la Biblia. En sus páginas se manifiestan más razones que exhortan a la caridad a los pobres y necesitados, como demuestran las palabras de Cristo en el Evangelio de Mateo: Entonces dirá el Rey a los que están a su derecha: Venid, benditos de mi Padre, tomad posesión del reino preparado para vosotros desde la creación del mundo. Porque tuve hambre, y me disteis de comer; tuve sed, y me disteis de beber; peregriné, y me vestisteis; enfermo, y me visitasteis; preso, $y$ vinisteis a verme. $Y$ le responderán los justos: Señor, ¿cuándo te vimos hambriento y te alimentamos, sediento y te dimos de beber? ¿Cuándo te vimos peregrino y te acogimos, desnudo y te vestimos? ¿Cuándo te vimos enfermo o en la cárcel y fuimos a verte? Y el Rey les dirá: En verdad os digo que cuantas veces hicisteis eso a uno de estos mis hermanos menores, a mí me lo hicisteis. (Mt., 25, 34-40).

Así pues, tanto la idiosincrasia de la doctrina cristiana, como las posteriores legislaciones particulares suscitaron la partición de bienes pertenecientes a cada catedral, bienes que compondrían el legado a

\footnotetext{
${ }^{9}$ Alfonso X, Las Siete Partidas, eds. C. Wasick, R. Cossio y V. Colomer, Madrid, 1994, fol. 19v.
} 
las clases sociales menos favorecidas y que serían conocidos institucionalmente con el nombre de limosnas. En algunas catedrales, la institución de la limosna llegó a ser propietaria de un abundante patrimonio, construyéndose edificios destinados a tal fin, como sucedió en Girona o Barcelona. La Almoina de Lleida, además de dar alimento a un número determinado de pobres, ofreció ayudas a otras instituciones locales como los hospitales de Expósitos del Espíritu Santo y el de los Niños Huérfanos pobres, entre otros ${ }^{10}$. Señalar aquí que las funciones ejercidas por las limosnas difieren de las llevadas a cabo por otras instituciones, también dependientes del cabildo catedralicio, como son los hospitales o las alberguerías, donde se daba acogida a enfermos y también pobres y peregrinos ${ }^{11}$.

Volviendo a la Almoina leridana, desconocemos su fecha de fundación, si bien se ha planteado como anterior a la data del 29 de abril de 1168, día en el que el primer obispo de Lleida, Guillem Pere de Rabidats, organizó el Cabildo de la Catedral sin olvidar a los pobres, cuyo socorro era un deber del Prelado, y a los cuales destinaba la décima parte de las posesiones de la mensa común de los canónigos porque el don de la limosna es cosa agradable a Dios según testimonio de la Sagrada Escritura ${ }^{12}$. Según P. Sanahuja de este documento se extrae la existencia, ya

\footnotetext{
${ }^{10}$ P. SANAHUja, Historia de la beneficencia..., op. cit, p. 42 .

${ }^{11}$ Sobre estas instituciones catedralicias, E. CARRERO SANTAMARÍA, “La acogida a los peregrinos en los catedrales. Hospitales, alberguerías y limosnas", en El Camí de Sant Jaume i Catalunya, Actas del Congreso. Barcelona, Cervera, Lleida, 16-18 de octubre de 2003, en prensa.

${ }^{12}$ P. SAINZ DE BARANDA, España Sagrada, tomo XLVII, De la Santa Iglesia de Lérida en su estado moderno, Madrid, 1850, pp. 256-261, apéndice II; J. VILLANUEVA, Viage literario a las Iglesias de España, 22 vols., Madrid 1803-1852, t. XVI, pp. 252-259. P. SANAHUJA, Historia de la beneficencia...op. cit., pp. 42-43.
}

en 1168, de la Almoina como institución, argumentando tal afirmación a través de la donación que se hizo para la limosna de los pobres como un hecho ya existente. Se cuenta además con la firma, en dicho documento, del limosnero Odón -Signum Odonis Eleemosinarii- ${ }^{13}$. El documento es claro en este sentido y manifiesta, sin lugar a dudas, la voluntad de procurar la subsistencia a los menos favorecidos. La pregunta que cabría hacerse en este momento es la ubicación real de tal institución, si es que existió de manera específica en ese primer momento. La limosna a los pobres fue un hecho común a todas las catedrales, y de algunas de ellas se ha conservado el edificio medieval donde se acogía a los indigentes y demás receptores de la ayuda dada por el cabildo; aunque hay casos en los que sabemos que el óbolo diario se daba en el mismo refectorio de los canónigos. En Lleida, y en estas tempranas fechas de las que estamos hablando, cabría suponer que así fue, aunque se ha dudado de tal aserto debido a otra noticia documental tan sólo unos días posterior a la anterior -7 de mayo de 1168 en la que se indica que en el refectorio donde comían los canónigos bajo regla se prohibía comer o servir a personas que no perteneciesen al clero Statuimus etiam ut in refectorio nostro nuilus comedat vel serviat nisi sit clericus $^{14}$. Pero lo que manifiesta esta noticia es el hecho de que la comida que se daba a los pobres no debía coincidir temporalmente con la de los canónigos de la catedral. El lugar, no obstante, era el mismo, ya que así sucedió siempre hasta la secularización, momento a partir del cual el refectorio de los canónigos, encontrándose sin uso debido a la ausencia de vida comunitaria,

-

${ }^{13}$ Ibid., pp. 43-45.

${ }^{14}$ P. SAINZ DE BARANDA, España Sagrada, op. cit., pp. 263-264, apéndice IV; J. VILlanUEVA, Viage literario..., op. cit., XVI, pp. 259-261. Recogido también en P. SANAHUJa, Historia de la beneficencia..., op. cit., pp. 4546. 
pasó a ser el espacio arquitectónico destinado a la refacción diaria de los pobres ${ }^{15}$. Esta circunstancia se repitió en un sinfín de ocasiones, ejemplo de las cuales fueron las catedrales de Girona ${ }^{16}$, Huesca ${ }^{17}$, Barcelo$\mathrm{na}^{18}{ }^{18}$ Toledo $^{19}$, o Salamanca ${ }^{20}$, entre otras.

${ }^{15}$ En 1254 se suprime la vida comunitaria de la catedral leridana (E. CARRERO SANTAMARÍA, "Sobre ámbitos arquitectónicos y vida reglar del clero. La canónica de la Seu Vella de Lleida", Seu Vella. Anuari d'història i de cultura, 3 (2001), pp. 82-107).

${ }^{16}$ En esta catedral se documenta, en 1315 , la costumbre de ofrecer dos colaciones en el refectorio. La primera correspondía a los canónigos obligados a la comida comunitaria en ciertos días festivos, mientras la segunda se dedicaba al personal restante entre el que, indudablemente, se hallaban los pobres. Sólo diez años después se decidió suprimir la segunda comida y trocarla por una cuantía en dinero -et pro secundo potu detur certa pecuniae quantitas- (J. VILlanUeVA, Viage literario...op. cit., t. XII, Viage a Urgel y Gerona, Madrid, 1850, p. 147).

${ }^{17}$ El 23 de julio de 1257 se realizó la reestructuración de la Almosna, y entre otras cuestiones se decidió que se diese diariamente de comer a diez pobres número que luego irá aumentando- en el refectorio de los canónigos, para entonces ya en desuso debido a la secularización (A. DURÁn GUDIOL, Historia de la Catedral de Huesca, Huesca, 1991, p. 66).

${ }^{18}$ J. BAUCELlS I ReIG, "La Pia Almoina de la Seo de Barcelona. Origen y desarrollo", A pobreza e a assistência aos pobres na Península Ibérica durante a Idade Média. Actas das 1"a Jornadas luso-espanholas de história medieval, Lisboa, 25-30 sept., 1972, tomo I, Lisboa, 1973, pp. 73135, en especial p. 89; C. BATLLE I GALLART, L'assistència als pobres a la Barcelona medieval (s. XIII), Barcelona, 1987, pp. 69-76; C. BATLLE I GALLART, I. DE LA Fuente i Castelló y J. Fernández-Cuadrench, "El clergat secular de la Barcelona del dos-cents segons els seus testaments", Analecta Sacra Tarraconensia, vol. 71 (1998), Miscel-lània Àngel Fàbrega, pp. 77-114, en especial pp. 110-111.

${ }^{19}$ Durante la Edad Media, la puerta del claustro situada frente al Palacio episcopal, donde se daba la comida a los pobres, era denominada 'Puerta del Mollete' (E. CARRERO SANTAMARÍA, “La acogida a los peregrinos...", op. cit.

${ }^{20}$ Durante los siglos XII y XIII en Salamanca se dio de comer a los pobres en el refectorio de los canónigos (Ibid.)
La tarea organizativa y el sustento económico de la Almoina se repartía entre el cabildo catedralicio correspondiente creando incluso un cargo específico como fue el limosnero, que se ocupaba de la administración de dicha institución benéficay la caridad particular, a través de las fundaciones privadas de pobres o porciones claustrales y de la donación de bienes ${ }^{21}$. El limosnero o procurador de la Almoina leridana pasó de uno, en origen, a dos a partir de 1319. Éstos eran nombrados anualmente por el cabildo, al menos así sucede desde mediados del siglo XIV, momento a partir del cual contamos con documentación sobre el particular a través de los libros de Deliberaciones. Las tareas a desarrollar por dichos cargos nos vienen expuestas en una Consueta de 1435, donde se dice que el honorable Cabildo ha acostumbrado cada año elegir dos Canónigos y estos son llamados Limosneros y Procuradores Mayores de dicha Almoina, los cuales tienen cargo y son obligados a trabajar en las cuestiones y asuntos de dicha Almoina, visitar los lugares de ella, repasar los cabreos de los Procuradores Menores de la Almoina de tres en tres meses, establecer las posesiones que pagan censal a la misma, mirar con diligencia que las cuentas de los cargamentos y ventas de las posesiones vayan a la Casa de la Almoina; y cobra cada uno de ellos 150 sueldos $^{22}$. A estos dos personajes le seguía en la jerarquía el clérigo administrador o refector, cargo que podía ser llevado por un mismo personaje durante un número indefinido de años. Éste, que debía residir en la ciudad, se en-

\footnotetext{
${ }^{21}$ No hay que olvidar que el obispo era el administrador de todos los bienes de su iglesia y diócesis. En un documento de 1254 se alude a la Almoina de Lleida poniendo como administradores de dicha institución al obispo y al cabildo. Así fue hasta el siglo $\mathrm{XV}$, momento a partir del cual la documentación relativa a este tema menciona al cabildo como único administrador (P. SANAHUJA, Historia de la beneficencia..., op. cit., pp. 65-70).

22 Ibid., pp. 72-73.
} 
cargaba de recibir y distribuir el dinero de la Almoina bajo las indicaciones del cabildo, de regir y cuidar las distribuciones, recaudar el dinero que entraba en la Almoina, distribuir cada domingo cinco o diez sueldos entre los pobres enfermos de la ciudad, entre los hospitales y los presos y de repartir la refacción entre los pobres. Por todo ello cobraba cuatrocientos sueldos anuales, además de una porción claustral que, a partir del siglo XVI pasó a media porción ${ }^{23}$.

En cuanto a la dotación económica por parte del cabildo a la Almoina, en ocasiones, éste mismo la relegó a un segundo término, primando otras cuestiones como la construcción de la catedral. En 1237 el obispo de Lleida, Pere de Albalat, estableció que la décima de todos los diezmos de la catedral, además de otros bienes de la propia Seu consignados a la Almoina para que ésta ejerciese su caridad entre los pobres, fuesen cedidos a las obras de la catedral por aquel entonces en plena construcciónhasta la finalización de aquéllas, momento en el que le serían devueltos a la Almoina: Item statuimos quod de omnibus Praeposituris detur decima Operi Ecclesiae sive Fabricae, quousque sit Ecclesia consumata, postea tota décima Eleemosinae adjungatur et Pauperibus erogetur; Panis autem qui venerit ad oblationem in Ecclesia, Eleemosiane tribuatur ${ }^{24}$. A pesar de tal circunstancia, la Almoina contaba con otras pensiones anuales y posesiones que le proporcionaban un sustento económico seguro. A partir de la segunda década del siglo XIV -centuria de mayor esplendor de la Almoina- se estableció para la fundación de cada pobre un capital correspondiente a

\footnotetext{
-

${ }^{23}$ Ibid., pp. 74-75.

${ }^{24}$ J. VILLANUEVA, Viaje literario..., op. cit., XVI, p. 136; P. SAnAhUJA, Historia de la beneficencia..., op. cit., pp. 48, nota 5. Curiosamente la décima de los diezmos extraídos de la Almoina no le fueron devueltos nunca, tal y como lo constató en 1613 el obispo de Lleida Francisco Virgilio (Ibid., pp. 51-52).
}

su manutención, creando uno o varios censales de tal forma que produjesen al año una pensión de cien sueldos, de los cuales noventa se designaban a la porción claustral -noventa sueldos al año o tres dineros diarios- y los diez sueldos restantes se destinaban a gastos de administración ${ }^{25}$. Asimismo se realizaban donaciones, tanto de personajes eclesiásticos como laicos, que contribuían a dotar la refacción diaria a los pobres. Un caso interesante es el de los donados al cabildo, quienes entregaban toda su hacienda a cambio de realizar tareas de mantenimiento en la catedral y recibían en compensación su sustento en la Almoina. Tal es el caso del presbítero Joan Escolar quien, el 31 de julio de 1226, se donaba a sí mismo y sus bienes, consistentes en una bodega con los utensilios propios de ella, dos viñas y tierras contiguas, ciertas casas de la Zuda o Castillo y un granero en la parroquia de San Lorenzo ${ }^{26}$.

Las fundaciones de pobres fueron casi siempre mandas testamentarias que indicaban el número de pobres instituidos $\mathrm{y}$, en ocasiones, quiénes debían $\operatorname{ser}^{27}$. Los nom-

${ }^{25}$ Ibid., p. 114.

${ }^{26} \mathrm{Su}$ donación fue aceptada y este personaje pasó a ser el limosnero, administrador y procurador de la Almoina, al menos que sepamos documentalmente, entre 1233 y 1240 (P. SANAHUJA, Historia de la beneficencia..., op. cit., pp. 56-58 y 110; apéndice documental V).

${ }^{27}$ El fundador expresaba la identidad de los pobres beneficiados, que eran normalmente los de su familia, en el caso de haberlos, ya que se aconsejaba socorrer a un pariente pobre antes que a un extraño (C. LÓPEZ AlONSO, La pobreza en la España Medieval, op. cit., pp. 267-268): Vull que dels dits cent $i$ milia sols., $e$ alberch e de ço que de aquells sera procehit de loguers e de renda sien fetes quatre parts eguals, la una de les quals sia distribuida a pobres vergonyants e catius a rembre especialment parents meus... (Testamento de Pere Soler, Arxiu del Palau, Lligall 361, c. 30, fol. 2r., según A. BoRRÀs I FeliU, "L'ajuda als pobres en els testaments de Catalunya i València del segle XV", en La pobreza y la asistencia a los pobres en la Cataluña Medieval, Barcelona, 1980, pp. 363-371, en especial p. 367). 
bres de los fundadores con sus escudos o armas y el número de pobres instituidos eran escritos en las paredes de la Almoina leridana, de igual modo a como se hizo en otros refectorios catedralicios ${ }^{28}$. En el de Lleida, además de las inscripciones que se han conservado, contamos con las representaciones pintadas de los propios pobres, siendo éste último hecho una práctica habitual, tal y como nos lo manifiesta el testamento del Arcediano de Benasque Capdevila Calvó, con fecha 5 de septiembre de 1386. En él se explicita la voluntad de ceder todos sus bienes a la Almoina, con la finalidad de que ésta instituyese a tantos pobres como fuese posible, ordenando además que los predichos pobres sean pintados en la pared según es costumbre hacerlo ${ }^{29}$. Existen además, como testimonio de esta actividad, las lápidas e inscripciones funerarias de la catedral y claustro, donde también se hacían constar los pobres instituidos por los respectivos fundadores ${ }^{30}$. Para otras catedrales, conser-

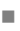

${ }^{28}$ También en los muros del refectorio de la catedral de Barcelona se escribieron el nombre de los fundadores y el número de pobres instituidos (J. BAUCELlS I ReIG, “Gènesi de la Pia Almoina de la Seu de Barcelona: els fundadors", en La pobreza y la Asistencia a los pobres en la Cataluña Medieval, Barcelona, 1980, pp. 17-75).

${ }^{29}$ Publ. P. SANAHUJA, Historia de la beneficencia..., op. cit., pp. 61-62.

${ }^{30}$ Al respecto Juan Heredia, archivero del Cabildo, redactó en 1543 y bajo el título Liber institutionum Rationum pauperum todas estas instituciones de porciones que apararecían diseminadas por la catedral, y que ascendían a la suma de 126 fundadores. Un ejemplo de estas lápidas mortuorias es la del arcediano de Tarantona y canónigo y prepósito de Valencia Raymundo de Montañana, que nos dice: En el año del Señor MCCCIX, 26 de septiembre, murió el venerable señor Raymundo de Montañana, Arcediano de Tarantona y Canónigo y Prepósito de Valencia, el cual instituyó cuatro Capellanías, la primera aquí donde se halla sepultado, la segunda en la Iglesia de Algecira de la cual fue párroco durante mucho tiempo, la tercera en Valencia, la cuarta en Montañana, de donde era oriundo. Instituyó también siete pobres perpétuos para ser alimentados en el claustro de Lérida y tres para ser vamos documentación relativa a estas fundaciones particulares ya que, en lo que atañe al testimonio pintado, apenas contamos con ejemplos ${ }^{31}$. En cuanto a los pobres que acudían a la Pia Almoina, existieron diferentes categorías que los diferenciaban en razón de los bienes recibidos de la institución benéfica. Aquéllos que tenían una porción u óbolo diario eran los denominados pobres ordinarios o diarios. Los llamados extraordinarios recibían su comida o dinero en un día determinado -el día del fallecimiento o aniversario de la muerte del fundador- o bien durante un tiempo limitado. Se dio también la circunstancia de media porción o medio pobre, lo que signifi-

sustentados en la Almoina de Valencia. Fundó todavía para los pobres cuatro piezas de paño blanco de Magdalena en Lérida para ser repartidas entre ellos a la entrada del invierno, y dos piezas en Valencia, y cien alnas de estopa de lino para ser distribuídas entre los pobres de Lérida al principio del verano con el objeto de recomponer sus ropas de vestido. Descanse en paz su alma. Amen (Publ. P. SANAHUJA, Historia de la beneficencia..., op. cit., pp. 62-64).

31 Así sucede en un documento con fecha 1 de mayo de 1227 , donde el maestro Martí -presbítero y rector del altar del santo Sepulcro de la seo de Barcelonaescribe: Instituo tres pauperes imperpetuum in Canonica Sedis Barchinone in hunc modum ut singulis diebus continuis assumantur tres, nullo delectu habito vel differencia personarum sed uniuscuisque pauperis secundum Deum, miseria et egestate pensata, nisi forte contingerit aliqua de cognacione mea venire ad tantam egestatem quod non posset sibi victum ad nature sustentacionem adquirere. Tunc enim si de cognacione et egestate constiterit et intuitu misericordie exegerit recipiatur, ita quod de numero illorum trium sit quandiu recipere voluerit et inopia laboraverit. Comedant autem ipsi tres pauperes in simul cum aliis assuetis pauperibus in refectorio dicte Sedis (J. BAUCELLS I REIG, "La Pia Almoina de la Seo de Barcelona...", op. cit., p. 90). De igual manera, hemos visto al respecto el caso de Ramón de Montañana -nota anterior-. Existen también noticias sobre fundaciones referidas a la Almoina de la Seu d'Urgell, institución piadosa ésta que pasó por momentos críticos hacia mediados del siglo XIV debidos en parte a la peste negra- seguidos de varios intentos de restablecimiento (vid. C. BATLLE I GALLART, La Seu d'Urgell medieval: la ciutat $i$ els seus habitants, Barcelona, 1985, pp. 119-125). 
caba una ración durante seis meses al año ${ }^{32}$. Ya en el siglo XV hubo porciones claustrales que no se vincularon estrictamente a un pobre, sino a un cargo, como fueron el maestro de canto de la Seu, el sacristán mayor o el cerero, entre otros ${ }^{33}$. También los hubo que no recogían diariamente su porción monetaria sino que recibían la cantidad correspondiente a todo el año de una vez, siendo éstos últimos, por lo general, pobres de familias nobles ${ }^{34}$, circunstancia que se fue generalizando con el tiempo, y con la que, no obstante, el cabildo se mostró en desacuerdo ${ }^{35}$.

El número de unos y otros pobres fue variando a lo largo de la Edad Media, dependiendo de las guerras o problemas económicos de la Almoina que, en circunstancias negativas, repercutía en la supresión de porciones claustrales. Incluso la dotación a los pobres extraordinarios fue interrumpida durante un periodo de varios años, en la segunda mitad del siglo XIV y hasta 1429 para, más tarde, -en 1461- ser eliminada totalmente $^{36}$. Comienza entonces, entre finales de siglo XV y principios del XVI, una nueva manera de ejercer la caridad por parte de la Almoina, a través de dotaciones económicas a instituciones religiosas o piadosas -hospitales o conventos- o bien a algún particular. Ejemplo de los numerosos casos son, en 1524, la viuda Alanyony a quien se le otorgó una porción claustral para sus necesidades; Miguel Juan Pullás, monaguillo cantor de la catedral, a quien en el mismo año se le dio también una porción para pagar sus estudios, o bien el Hospital

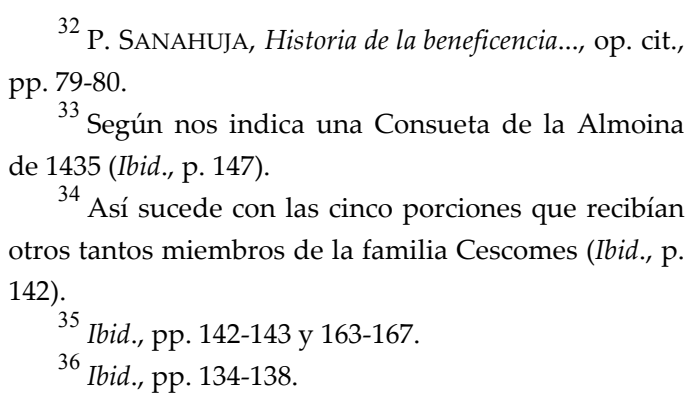

${ }^{32}$ P. SANAHUJA, Historia de la beneficencia..., op. cit., pp. $79-80$.

${ }^{33}$ Según nos indica una Consueta de la Almoina de 1435 (Ibid., p. 147).

${ }^{34}$ Así sucede con las cinco porciones que recibían otros tantos miembros de la familia Cescomes (Ibid., p. 142).

${ }^{35}$ Ibid., pp. 142-143 y 163-167.

${ }^{36}$ Ibid., pp. 134-138.

General y el Hospital de los Pobres Huérfanos, a quienes en 1576 y 1577 la Almoina dio sendas porciones ${ }^{37}$.

El modo en que se repartía la limosna también sufrió cambios a lo largo del Medievo. En un principio, como hemos ido viendo, se daba la ración alimenticia diaria en el refectorio de la catedral, pero en un momento no demasiado claro empezó a entregarse una cantidad equivalente en monedas para que los propios pobres se proveyesen del alimento. El óbolo monetario se entregaba durante la misa, en la capilla de la Almoina situada en el interior del mismo refectorio, siendo la pensión dada por pobre y año de, aproximadamente, cien sueldos anuales o bien tres dineros diarios. Según P. Sanahuja habría que fechar el aludido trueque de monedas por viandas a mediados del siglo XIV, ya que en 1349 se instituyó un pobre para ser alimentado o provisto reficiendum seu prouidendum, y años más tarde, entre 1357 y 1358, según la Libreta de los pobres de la Almoina se dieron tres sueldos a algunos pobres ${ }^{38}$. Quizás se simultaneó el alimento a algunos y el dinero a otros, porque existen datos que nos llevan a pensar que se mantuvo la refacción con viandas, al menos en parte, hasta mediados del siglo $\mathrm{XV}$, pocos años antes de que el Cabildo -en 1477- cediese el refectorio de la Almoina a la Cofradía de Clérigos Pobres -denominados de San Salvador a partir de 1327, al ocupar la parroquia de dicha advocación, sita extramuros de la ciudad- ${ }^{39}$. Como anunciaba líneas arriba, sabemos de la celebración de un Concilio en el espacio de la Almoina -en 1418- para el

-

${ }^{37}$ Ibid., pp. 145-147 y en especial pp. 168-180.

${ }^{38}$ Ibid., p. 159.

${ }^{39}$ Ibid., pp. 107-108; J. TRENCHS ODENA Y F. LARA Peinado, "La Casa de Caridad y la Cofradía de los Clérigos Pobres, dos instituciones medievales leridanas. (Documento inédito relacionado con ellas)", Ilerda, XXXVI (1975), pp. 7-36. 
cual se gastaron veintisiete sueldos y seis dineros en aderezar el lugar, sacando de él las mesas y arreglando los bancos ${ }^{40}$, unas y otros evidentemente necesarios para disponer a los pobres a comer. Por otro lado existe también una Constitución capitular de 1367, de la que hablaremos más detenidamente en páginas sucesivas, que con el título De presentatione pauperis claustri, nos explica cómo colocaban a los pobres en sus respectivos lugares dentro del refectorio para que no se produjesen peleas o discordias ${ }^{41}$. Tal circunstancia es una muestra evidente de que, al menos a algunos pobres, se les estaba dando la refacción en forma de comida. De igual modo, dos conocidas noticias - una de 1368 y otra de 1457- muestran asimismo indicios que dejan entrever, en los mencionados años, un uso del refectorio de la Almoina como tal. La primera de ellas es un testamento en el que el arcediano de Benasque Capdevila Calvó legó parte de sus bienes a los pobres del claustro de la catedral leridana, determinando que los predichos pobres sean pintados en la pared según es costumbre hacerlo ${ }^{42}$. Más adelante veremos cómo la representación de los pobres, con las inscripciones de los fundadores en los muros de la Almoina mucho tiene que ver con el lugar ocupado por aquéllos, siendo un signo inequívoco de la utilización del refectorio para tal fin. De la misma manera se explica la noticia ya aludida de 1457, gracias a la cual sabemos de unas obras realizadas en el edificio y ante la destrucción de uno de sus muros se llamó a un notario para que tomase nota de las inscripciones de los fundadores y sus armas con la finalidad de ser copiados de

\footnotetext{
${ }^{40}$ P. SANAHUJA, Historia de la beneficencia..., op. cit., p. 106

${ }^{41}$ Arxiu Capitular de Lleida [A.C.L.], Constitutiones Ecclesiae Cathedrali Ilerdensis, cajón 218, fol. 51r.-v.

42 P. SANAHUJA, Historia de la beneficencia..., op. cit., pp. 61-62.
}

nuevo, tras la obra ${ }^{43}$. Otra confirmación de la hipótesis formulada líneas arriba nos la trae la ya nombrada Consueta de la Almoina de 1435 y en la que podemos leer: Item lo dit honorable Capitol antigament hacostumaua he encara acostuma de metre tans studians gramatichs com coneix que la dita Almoyna pot soportar en la dita Almoyna, tres dies a la sepmana de la festa de tots Sans fins a Cinquagesima, com daqui auant los studians artistes noi aturen pus ho són pochs e açó es una santa cosa per tal com ja la Almoyna, ha agut bé de temps passat de studians quiu auien pres de aquesta Almoyna, per qué en res no deuen romayr que non entren quiscum any ${ }^{44}$. Es evidente aquí que la cabida de los estudiantes en la Almoina se refiere a la ración alimenticia y no al óbolo monetario.

El hecho comentado de cambiar el alimento diario por la porción en monedas no fue exclusivo de la Almoina que aquí estamos tratando. Lo mismo sucedió en Barcelona a partir del siglo $\mathrm{XV}$, cuando en una constitución del 16 de mayo de 1421 se especificaba que, a partir de aquél momento, se suprimía el servicio del refectorio por la entrega de un pan de dieciocho onzas y de cuatro dineros. Este cambio se produjo por los problemas que veían de la celebración diaria de la comida, debido al gran gasto extra que ello suponía, ya que además de pagar los lógicos alimentos, también estaba la leña, el agua, la sal, los utensilios de cocina, los vasos, platos o jarras -que muchas veces se rompían y había que reemplazar por nuevos-, y eso sin contar las pérdidas o robos que se producían en una entidad de tales características ${ }^{45}$. Pero si

43 A.C.L., Manuale Deliberationum...Capituli, años 1457-1467, n. 91, fol. 7 v., según P. SANAHUJA, Historia de la beneficencia... op. cit., p. 62, nota núm. 28.

${ }^{44}$ Publ. P. Sanahuja, Historia de la beneficencia..., op. cit., p. 175, nota 227.

${ }^{45}$ J. BAUCELls I ReIG, "La Pia Almoina de la Seo de Barcelona...", op. cit., p. 110, apéndice documental no ${ }^{\circ}$, pp. 119-120.
} 
esta orden se llevó a cabo, no debió ser durante mucho tiempo o bien no con todos los pobres, porque ocho años después sí se cerró el refectorio, debido al derribe de la cocina para poder seguir construyendo el ala noroeste del claustro. De hecho, el 21 de julio de 1429 se volvió a legislar sobre el tema. Entonces, se substituyó la refacción diaria por cuatro dineros los días de carne y tres dineros los días cuaresmales y de vigilia. Continuó, eso sí, la distribución del pan. Unos años más tarde, construido ya el nuevo edificio de la Almoina barcelonesa, se volvió a la refacción en el comedor, como en los primeros tiempos, durante la cual y según lo dispuesto en 1226 por Berenguer de Palou, se leía en voz alta algún libro piadoso como podía ser el Legender Santorial para, de esta forma cuidar el espíritu de los pobres, además de velar por su bien físico ${ }^{46}$. Ésta debió ser una costumbre habitual en todas las Almoinas, ya que tenemos noticias de que Pere Compte construyó, en el siglo XIV, un púlpito para las lecturas en la $\mathrm{Al}$ moina de la catedral de Valencia; que posteriormente fue trasladado a la sala capitular o Capilla del Santo Cáliz ${ }^{47}$. Nos consta también la existencia de un púlpito para las lecturas en el gran refectorio de la catedral de Tarragona y, en el caso de la limosna de la Seo de Huesca, hemos conservado su hoy deteriorado púlpito de yesería ${ }^{48}$.

En cuanto a la alimentación dada a los pobres en los refectorios medievales encontramos siempre una dieta $\mathrm{u}$ otra según las diferentes épocas litúrgicas del año. Gracias a diversos manuscritos conocemos con detalle los alimentos dados. En 1302, la

\footnotetext{
${ }^{46}$ Ibid., p. 111-112.

${ }^{47}$ J. VilLANUEVA, Viage literario... op. cit., tomo I, Viage a Valencia, p. 31.

${ }^{48}$ B. CABAÑEro Subiza, "Estudio de los tableros parietales de la mezquita aljama de Huesca, a partir de sus réplicas en el púlpito de la Sala de la Limosna. Notas sobre las influencias 'abbasíes en el arte de alAndalus", Artigrama, no 11 (1994-1995), pp. 319-338.
}

Almoina de Huesca socorría diariamente a veinticinco pobres, a los que se alimentaban con dos libras y media de pan a cada uno de ellos, y otras tantas de vino aguado, acompañado los domingos, martes y jueves de un cuarto de cordero para cada diez pobres, con un dinero de salmorejo, y los lunes, miércoles, viernes y sábados -días de abstinencia- sopa de cebolla y seis libras tres onzas de queso. En Adviento y Cuaresma, los domingos, martes y jueves verdura o legumbres con aceite y congrio con salmorejo $^{49}$. En la Almoina de Barcelona se daba cada día a los pobres -el número de éstos fue variando en las distintas épocaspan, vino, escudella-barrejada, o bien, en algunos momentos como acabamos de ver, el equivalente de los alimentos en dinero ${ }^{50}$. En el refectorio leridano, y gracias al Llibre de les despeses del minjar del pobres de la Claustra... feites per en Berenguer Calbuç Administrador del dits Pobres en las de mil e CCC XXXVIII, sabemos que en dicho año el refectorio de la Almoina, donde trabajaban una cocinera, dos sirvientas y un comprador, dio de comer nada más y nada menos que a treinta y dos mil ochocientos sesenta y ocho pobres. Que los Paheres del Ayuntamiento de Lleida, en determinados días, iban al refectorio para repartir alguna mealla (medio dinero de Lleida); que el trigo, el aceite, y el congrio se encontraban entre las expensas extraordinarias y que todos los gastos, tanto estos últimos como los ordinarios ascendían a ocho mil cientoún sueldos con ocho dineros ${ }^{51}$.

\footnotetext{
49 A. DuRÁn Gudiol, Historia de la Catedral de Huesca, op. cit., p. 93.

${ }^{50}$ Un libro de cuentas de la almoina barcelonesa de 1283 nos permite saber los alimentos utilizados para la refacción diaria a los pobres, según las distintas fiestas litúrgicas del año (C. BATLLE I GALLART, L'assistència als pobres... op. cit., p. 71-74).

${ }^{51}$ P. SANAHUJA, Historia de la beneficencia..., op. cit., p. 102; P. BERTRÁN I ROIGÉ, “El menjador de l'Almoina
} 
Seguramente tal cantidad de pobres hizo que el orden y lo cotidiano en la vida de los canónigos leridanos se viesen truncados de tal forma, que se llegó a tratar el tema en unas Constituciones capitulares de 1372. Bajo el título De correctione pauperum claustri establecían Item que per procuratores maiores pauperum claustri sedis ilerdense eligatur quolibet anno aliqua bona persona ad ec conveniens et apta qui singulis diebus haveat stare et residere in predicto claustro a prima usquequo pauperes exiuerint de ipso claustro cum suis qui corrigat et castigat pauperes et specialiter pueros ne vixentur nec iaciant lapidus neque clament seu vocifferent dum in ipso claustro fuerint et si tales fuerint qui verberari non possint que mandet aufferi talibus porcionem sive elemosinam illius dieyi allii qui non habuerit tribuendam per refectorem ipsorum pauperum et ista persona taliter electa habeat pro hoc labore unam racionem continue dum in hiis bene se habuerit et non alter ${ }^{52}$.

Ya hemos visto cómo, casi un siglo después, en 1477, el Cabildo cedió el espacio de la Almoina a la Cofradía de Clérigos Pobres. A pesar de ello la institución piadosa capitular seguía ubicada en el mismo lugar y el administrador o un auxiliar daba la caridad a los pobres, tras la misa diaria que se celebraba en la capilla ${ }^{53}$. No obstante, la Almoina tuvo otras funciones secundarias, como el mantenimiento del culto en algunas capillas, el proveer tres lámparas de la catedral ${ }^{54}$, así como también debía

de la Catedral de Lleida. Notes sobre l'alimentació dels pobres lleidatans al 1338", Ilerda, XL (1979), pp. 89-124.

52 A.C.L., Constitutiones Ecclesiae Cathedrali Ilerdensis, cajón 218 , fol. $48 \mathrm{r}$.

${ }^{53}$ P. SANAHUJA, Historia de la beneficencia..., op. cit., pp. 107-108; J. TRENCHS ODENA Y F. LARA PEINADO, "La Casa de Caridad y la Cofradía de los Clérigos Pobres...", op. cit.

${ }^{54}$ Una ardía sin interrupción en el altar mayor, ante el Santo Pañal; otra se situaba en la capilla de la Santa Trinidad, fundación de Berenguer de Artesa, de quien fue heredera la Almoina, y una tercera en el altar encargarse de enramar y enjuncar la capilla de la Trinidad en la vigilia de su fiesta y tener preparadas candelas, para las procesiones que se realizaban en dicha capilla los días de su festividad ${ }^{55}$. Del mismo modo y ya antes de ceder el espacio del refectorio a la Cofradía de Clérigos Pobres, aquél sirvió como lugar donde desarrollar actividades ajenas a su fin originario. Así sucedió en 1418 cuando, entre los meses de octubre y noviembre se celebró en dicho espacio el ya aludido concilio o, en 1448, año en que se realizaron los exámenes de los Doctores del Estudio Ilerdense en la Almoina, ya que la Casa de la Cancillería, donde acostumbraban a hacerse, estaba siendo restaurad $a^{56}$. Igualmente, de las arcas de la Almoina salían los salarios de los capellanes y algunos de los oficiales de la catedral -entre ellos los cantores y músicos-, situación con la que acabaría, en el siglo XVII, el obispo Francisco Virgilio quien, en una visita pastoral a la catedral entre 1613 y 1615, reprochaba dicha circunstancia ya que el dinero de la Almoina debía destinarse a aliviar las necesidades de los pobres ${ }^{57}$.

de la capilla de la Almoina, dotada por Vila Calvó, Arcediano de Benasch, en su testamento de 1386 (P. SANAhUJa, Historia de la beneficencia..., op. cit., pp. 7576).

${ }^{55}$ Ibid., p. 76. Sobre las festividades litúrgicas medievales en la vieja seo ilerdense, F. FITÉ I LLEVOT, "Litúrgia i cultura a la Seu Vella de Lleida", en Seu Vella, l'esplendor retrobada, Lleida, 2003, pp. 98-129.

${ }^{56}$ P. SANAHUJA, Historia de la beneficencia..., op. cit., pp. 105-106.

${ }^{57}$ Ibid., pp. 179-180. A mediados del siglo XVI se tomó dinero de la Almoina para pagar la capilla de cantores y monaguillos de coro de la catedral, ya que no había otra institución que pudiese subvencionarla. Esta cuestión llegará a época moderna no exenta de controversias, y a las que en 1743 algunos canónigos favorables a tal patrocinio respondieron: $Y$ porque desde aquel tiempo (siglo XVI) en casi todas las Iglesias Catedrales de este Reino se daba entrada a las Capillas de Músicos y Cantores para la Salmonia y Alabanzas Divinas, y como los Canónigos de entonces, Administradores de la Almoina, 
Siguió la Almoina como institución durante toda la Edad Moderna, hasta principios del siglo $\mathrm{XX}$, aunque bien es cierto que las guerras que vio durante todo este período, los gastos que ocasionó la construcción de la nueva catedral y más tarde, en 1837, la supresión de los diezmos por ley, menguaron su capital, su influencia social y, sobre todo, la caridad a los pobres y necesitados, al fin y al cabo su razón primera y principal. Fue ya en el siglo XIX, con la ley sobre beneficencia pública de 1822 y el real decreto de 1836, el momento en el que se obligó a la institución pía a no expender su dinero en cuestiones ajenas a la caridad, invalidando así el decreto del obispo Galindo de 1754, el cual permitía la dotación económica por parte de la Almoina de los músicos y cantores $\mathrm{u}$ otros oficiales eclesiásticos una vez cubiertos los gastos correspondientes a la asistencia de los pobres $^{58}$.

\section{PINTURAS DE LA 'ALMOINA' DE LLEIDA. ANÁLISIS Y CRONOLO- GÍA}

El conjunto de pintura mural que estudiamos se encuentra ubicado en la actualidad sobre paneles, custodiados en el $\mathrm{Mu}-$ seu Diocesà i Comarcal de Lleida, pero en un principio ocupó los muros del refectorio de la Almoina de la Seu Vella. Gracias a fotografías tomadas en el momento de la restauración del edificio, antes de ser arrancadas las pinturas del muro, podemos conocer de manera certera el emplazamiento

vieran que a ellos tocaba el mirar por el decoro de la Iglesia Catedral y el aumento del culto divino, no dudaron un punto de expender de los fondos de la Almoina lo que creyeron conveniente para el sostenimiento de los músicos, puesto que esto llevaba ventaja a todo lo demás en piedad y caridad. $Y$ para seguridad de sus conciencias acudieron al Sumo Pontífice Paulo IV (publ. P. SANAHUJA, Historia de la beneficencia..., op. cit., pp. 184-185).

$$
{ }^{58} \text { Ibid., pp.193-268. }
$$

de algunos de los fragmentos conservados en su espacio arquitectónico originario ${ }^{59}$. Así pues, los paneles pictóricos, hoy con número de inventario 2 y 4 , se ubicaban en el muro norte (Fig. 1) ${ }^{60}$, mientras que las catalogadas con el número 1 se encontraban frente a las anteriores, en el muro sur (Figs. 2 y 3$)^{61}$. Desafortunadamente no existe el mismo documento gráfico para los muros oriental y occidental, razón que nos impide dar una propuesta hipotética del emplazamiento de otros fragmentos pictóricos, aunque sí tenemos la evidencia documental de que dichos muros estuvieron también decorados con pinturas. Ya vimos cómo en 1457 se realizaron obras en la Almoina para agrandar dicho espacio y se acordó que un notario tomase nota de las representaciones de los pobres, títulos y armas de los fundadores con la finalidad de volverlos a pintar en las paredes, una vez acabadas las obras: Attendentes etiam quod in parietibus Domus ubi de presenti datur elemosina, sunt depicti

-

59 Aunque las fotografías existentes del momento de la restauración se conservan en el Arxiu Ferrant (Col-legi Oficial d'Arquitectes de Catalunya, Demarcació Lleida), las que aquí se publican proceden del Arxiu Mas (Barcelona) ya que esta institución, al contrario que la anterior, no se mostró reacia a mostrar sus fondos fotográficos ni negó la existencia de parte de ellos.

${ }^{60}$ Los frescos se colocaron en paneles, con números de inventario del 1 al 6 . Aunque son siete los fragmentos pictóricos dos de ellos comparten un mismo número de inventario -2-, razón que se explica seguramente a que el gran tamaño de éste hizo difícil hacer de él un solo panel, perteneciendo ambos como lo hacen a una misma campaña pictórica y ejecución.

${ }^{61}$ Otra hipótesis propuesta al respecto ha sido la de J. Sureda, quien plantea que los paneles con número de inventario 1 y 5 se ubicaban en el muro meridional, los correspondientes a los números 2 y 3 en el occidental, el 4 en el septentrional, y el número 6 en el muro oriental (J. SUREDA i PONS, "Decoració mural del refectori de la Seu Vella de Lleida", op. cit., p. 108; Id., "Pintures murals de la Pia Almoina", en Catàleg de l'Exposició 'Pulchra', Lleida, 1993, no 124, pp. 85-86, en especial p. 85). 
pauperes et tituli illorum qui instituerunt dictos pauperes, fuit ordinatum per dictum honorable Capitulum quatenus notarius dicti honorabilis Capituli scribat titulos descriptos in dictis parietibus, et quod (quot) pauperes instituit quilbet (quilibet) scribendo que arma sunt in dictis parietibus posita per illos qui instituerunt dictos pauperes et cuius coloris. Et ex quo dicte Domus fuerint perfecte, dicti pauperes de nouo depingantur eo modo quo sunt et prout munch de presenti sunt depicti ${ }^{62}$. Probablemente, como ya se ha dicho, además de las representaciones pictóricas que aquí estamos tratando, hubo también pequeñas tablas con los nombres y heráldica de los fundadores de las raciones de pobres ${ }^{63}$.

Los diferentes fragmentos de las pinturas de la Almoina leridana comprenden un amplio abanico cronológico que va desde el siglo XIV hasta los años que engloban la primera mitad del XVI. Los más tempranos -número de inventario 2- son asimismo los más conocidos ya que han sido objeto de un mayor número de estudios debido,

62 A.C.L., Manuale Deliberationum...Capituli, años 1457-1467, n. 91, fol. 7 v, publ. P. SANAHUJA, Historia de la beneficencia..., op. cit., p. 62, nota núm. 28. El motivo de dicha ampliación fue la reestructuración de todo el espacio de la vieja canónica ilerdense, entre cuyas estancias se encontraba el refectorio, y que fue subdividido desde sus dos espacios originales -la sala capitular o capilla de Santa María la Vella y el propio refectorio- en tres, es decir, un nuevo capítulo, el refectorio de la Almoina y la capilla de Santa María la Vella como espacio autónomo. Para este proceso de transformación y la identificación de las dependencias, E. CARrero SANTAMaría, "La Mezquita mayor, Santa Maria l'Antiga y la canónica de la Seu Vella de Lleida. Historia de una confusión", Actas del XIII Congreso CEHA. Ante el nuevo milenio. Raíces culturales, preyección y actualidad del arte español, Granada, 2000, vol. I, pp. 65-74 e Id., “Sobre ámbitos arquitectónicos y vida reglar...", op. cit., pp. 180-189.

${ }^{63}$ J. YARZA LuACES, "Pintures murals de la Pia Almoina", La Seu Vella de Lleida. La catedral, els promotors, els artistes, s. XIII-S. XV, Barcelona, 1991, pp. 100102, en especial p. 101. con probabilidad, al hecho de que también son aquéllos mejor conservados, si bien es cierto que han sufrido una fuerte restauración, fácilmente perceptible con una simple visualización al estado de los frescos en la actualidad y de las fotografías antiguas, anteriores a dicho proceso (Figs. 4, 5, $6 \mathrm{y}$ $7)^{64}$.

Estamos ante una representación figurada que, en líneas generales, se va a ir repitiendo en casi todos los restantes paneles pictóricos. La composición se estructura a través de una mesa ataviada de un largo mantel con profusos y reiterados pliegues, que recorre longitudinalmente el panel y

-

${ }^{64}$ J. GUDIOL RICART, "Las pinturas murales de la catedral de Lérida", Ciudad, núm. extraordinario dedicado a la Catedral Antigua, 1956, pp. 65-66; J. AINAUD DE LASARTE, "La historia de las pinturas de la Seu Vella", op. cit., pp. 5-7; W.W.S. COOK Y J. GUDIOL RICART, Pintura e imaginería románicas, col. Ars Hispaniae, vol. VI, Madrid, 1980 (2ª ed. actualizada), p. 193; J. YARZA LUACES, "Pintures murals de la Pia Almoina", op. cit.; J. SUREDA i PONS, "La pintura del primer gòtic a la Seu Vella de Lleida", Actes del Congrés de la Seu Vella de Lleida, Lleida, 1991, pp. 93-97, en especial pp. 96-97; Id., "Pintures murals de la Pia Almoina", op. cit.; R. AlCOY I PEDRÓs, "Pintura mural de la Pia Almoina", Santiago. Camino de Europa. Culto y cultura en la peregrinación a Compostela. Galicia no Tempo, Santiago de Compostela, 1993, pp. 327-330; A. CONEJO DA PENA, "L'almoina del claustre de la Seu Vella de Lleida", Seu Vella. Anuari d'história i cultura, no 1 (1999), pp. 103-146; C. Berlabé i Jové, G. Fernández SOMOZA, F. Fité I LLEVOT, “La pintura mural a Lleida (1300-1350): L'època de la fundació de l'Estudi General", en De pintura mural. A propòsit dels frescos de Josep Mingell $i$ Cardenyes al Campus de Ciències de la Salut de la Universitat de Lleida, Lleida, 2001, pp. 12-39, en especial pp. 2935; R. Alcoy I Pedrós, “Els cicles murals de la Seu Vella de Lleida. De les evidències a les reconstruccions ideals", en Seu Vella. L'esplendor retrobada, Lleida, 2003, pp. 67-78, en particular pp. 72-73; G. FERNÁNDEZ SOMOZA, "Iconografía y funcionalidad arquitectónica en la pintura de las Limosnas catedralicias en la Corona de Aragón", en Catedral y ciudad medieval en la Península Ibérica, eds. E. Carrero y D. Rico, Murcia, 2003, en prensa. 
bajo la cual, a pesar de ver sus patas, notamos la ausencia de los pies de los personajes que se encuentran comiendo, aunque sí se representa un perro mirando hacia la mesa, que volveremos a encontrar en otros paneles pictóricos de la misma Almoina (Figs. 8 y 9). Los comensales llenan el espacio superior, representados de medio cuerpo, de tal forma que parecen estar de pie. Sobre la mesa se dispone todo un ajuar consistente en jarras, cuencos y cuchillos, además de dos tipos de panes, uno redondo y otro alargado ${ }^{65}$. La unidad de esta composición sólo se rompe por líneas trenzadas que dividen la escena en grupos de personajes -uno, tres o cuatro-. Sobre todos ellos y cobijando de manera individual a cada uno, se figuraron arcos en mitra sobre pinjantes con decoraciones en las enjutas a modo de escudos heráldicos y de flores de tres largos pétalos. Y ya, sobre éstos, también a lo largo de todo el panel, encontramos inscripciones que refieren el nombre de quien instituyó uno o varios pobres en la Almoina, el número de éstos y el tipo de porción ${ }^{66}$. Las inscripciones del panel que ahora tratamos son las mejor conservadas y las que admiten, por tanto, una lectura más completa, habiéndose podido además, identificar los nombres que aparecen gracias a la rica documentación existente aún hoy sobre la catedral leridana ${ }^{67}$. Algunos de

-

${ }^{65}$ El primero de ellos, de tradición cristiana, es redondo, grande y más blando ya que lleva más cantidad de levadura, y el segundo, de tradición musulmana, mucho más cocido y duro, se cortaba en trozos alargados (P. BERTRÁN I ROIGÉ, "El menjador de l'Almoina...", op. cit., p. 95).

${ }^{66}$ Bien a perpetuidad, bien por un tiempo limitado o durante unos días específicos.

${ }^{67}$ Se conserva un manuscrito de asignación de censales para los pobres de la Almoina, fechado en enero de 1330, donde se relacionan el nombre de las personas que instituyeron pobres, el número de éstos y el tipo de porción. En dicha relación aparecen algunos nombres que se han identificado con varias de las inscripciones de las pinturas correspondientes al ellos fueron personajes insignes como son los casos de Pere del Rei y Jaume Saroca obispos de Lleida y Huesca respectivamente- ${ }^{68}$, o del arcediano de Ribagorça y tesorero de la Seu de Lleida Pere de Torrefeta ${ }^{69}$. Otros, en cambio, fueron individuos de un escalafón social más humilde, aunque poderosos económicamente hablando, como el mercader de draps de Lleida Ramon Cayró $^{70}$. Finalmente, la composición se cierra, en su zona inferior, por una cenefa decorativa formada por tallos que acaban en círculo y encierran una suerte de flores verdes de cuatro pétalos.

Hay en estos fragmentos de pinturas una mayor utilización de la línea sobre el color, propia del momento en que se ejecutó; aunque bien es cierto que este predominio de la línea existe en todos los paneles pictóricos de la Almoina, incluso en los más tardíos. Volviendo a los primeros frescos, decir que se adscriben estilísticamente a la corriente pictórica del primer gótico, llamada también gótico lineal, habiendo sido datados en torno a $1330^{71}$.

número de inventario 2 (P. SANAHUJA, Historia de la beneficencia... op.cit., pp. 79-81).

${ }^{68}: \mathrm{P}(\mathrm{E}) \mathrm{TR}(\mathrm{US})$ : D(E) REGE : EP(ISCOPU)S : ILERD(ENSIS) : I(NS)T(ITU)IT : IST(O)S : P(E)RPETUO. (SARR)OCHA : (EPISCOPU)S : OSCENSIS : INST(ITUIT) (I)S(T)OS : PERPETUO.

69 (P)ETR(US)D(E)TURRE : FACTA : ARCI (D)IACHO ... A $\quad$...DREI... : INST(ITUIT) ISTOS : $\mathrm{P}(\mathrm{ER}) \mathrm{P}(\mathrm{E}) \mathrm{T}(\mathrm{UO})$

${ }^{70} \mathrm{R}$... REI : DRAPER ... : INST(I)TUIT : IST(OS) ... (PE)RPETUO. Otras inscripciones que pueden leerse en parte son aquellas que aluden a Ramón de Montasor: ... : R : D(E)MONTASSOR ... : (I)NS(TITUIT) ... $\mathrm{P}$ (ERPETU)O; a un tal Juan: IOH(ANES) ... A ... INS(TI)TU(IT); a otras dos fundacinones de las que sólo podemos leer NTO ...(INSTI)TUIT : ISTO(S); y RA ... : AR ... A T(US) : ILE(R)DE(NSIS) IST(U)M ... (PERPET)UO.

${ }^{71}$ J. YARZA LuACES, "Pintures murals de la Pia Almoina", op. cit. 
La superficie inferior del panel con número de inventario 1 (Fig. 10) se estructura igualmente a través de una mesa larga sobre la que se disponen jarras, cuencos con comida, copas, cuchillos y los panes alargados a los que antes se hacía referencia. Tras ella se representó a diez personajes comiendo -dos femeninos y ocho masculinossituados, los dos de la izquierda, bajo arcos en mitra albergando trilóbulos. El resto se cobija bajo arcos, también en mitra pero con tracería compuesta por un círculo con un tetralóbulo que se apoya sobre un trilóbulo mayor, mientras en las enjutas se dispusieron decoraciones heráldicas. Dos líneas trenzadas dividen la composición en tres partes, aunque lo representado en toda ella comparte una misma iconografía alusiva a los pobres comiendo en el refectorio de la Almoina. Sobre todo este registro inferior restan inscripciones que sólo son legibles de manera fragmentaria. Aún así, nos manifiestan sin lugar a dudas su sentido, totalmente en consonancia con la iconografía representada y semejantes a las inscripciones comentadas anteriormente, procedentes del panel con número de inventario 2 . En una de ellas podemos leer: (US) : ALERI : INSTI(T)UIT : ISTUM : (PA)UPEREM : IN PER(PETU)O : CUIO : A(N)I(M)A ... SCA(?) : INPA... En la otra, aún más deteriorada solamente podemos deducir el nombre del fundador PETR(US) ... OUD ... Esta última inscripción se encuentra sobre otra que aún puede verse tímidamente, pero si ya el menoscabo de la anterior es grave, de ésta segunda se intuyen tan sólo letras, de forma que su lectura es imposible. Por último, decir que este fragmento podría encuadrarse cronológicamente dentro de la segunda mitad del siglo XIV, alejándose pictóricamente de los paneles anteriores mostrando unos rasgos muy italianizantes.

Continuemos con el panel correspondiente al número de inventario 3 (Fig. 11). Presenta un grave estado de deterioro, ya que no sólo muestra la pérdida total de algunas zonas de la pintura, sino también una mala conservación general de la superficie existente. La composición de la escena sigue estructurándose a través de una larga mesa en la que se disponen los personajes, cuyas piernas tampoco aquí se representan, y sí una de las patas de aquélla. Son nueve los comensales que se figuran en actitudes similares a las vistas hasta el momento, aunque no observamos, debido a los mencionados daños sufridos, los utensilios que seguramente se colocaron sobre la mesa. Volvemos a encontrar dos tipos diferentes de arcuaciones cobijando a los personajes. En la zona izquierda, cuatro figuras se encuentran bajo arcos en mitra que albergan tracería y decoraciones heráldicas en sus enjutas, en una composición casi exacta a los vistos en la parte derecha de la zona inferior del panel número 1 . Les sigue una línea trenzada dividiendo la escena y separándolos del resto de personajes, disgregados a través de líneas trenzadas en tres grupos -tres, uno y uno-. Éstos son cobijados por arcos en mitra sobre pinjantes con decoraciones en las enjutas a modo de escudos heráldicos y de flores de tres largos pétalos, exactamente iguales a los vistos en el panel con número de inventario 2. Solamente los pinjantes difieren entre uno y otro fragmento. Sobre las arcuaciones se disponen las inscripciones que siguen en su mayor parte siendo ilegibles, por el estado fragmentario en el que se encuentran. Solamente una de ellas, la situada más a la derecha, nos ofrece alguna luz al respecto: $\ldots \quad \mathrm{R} \quad$ : A... INST(ITUI)T : ISTU : PER(PE)T(U)OS. Nuevamente se alude aquí a la institución de pobres en la Almoina y al carácter de aquéllas que, en este caso se trataba de una porción diaria perpetua. Cierra la composición en la parte baja una decoración que recorre longitudinalmente toda la zona -aunque a la izquierda no se ha conservado-, y donde se representa una cenefa ornamental de tallos formando círculos que encierran flores de pétalos ver- 
des, siguiendo el mismo modelo visto en el panel número 2. En cuanto a la cronología parece claro que este fragmento sería posterior a los referidos anteriormente -número de inventario 2 y zona inferior del 1- ya que, como acabamos de ver, se copiaron los esquemas compositivos de aquéllos: las arcuaciones con las decoraciones florales y heráldicas en las enjutas, la cenefa vegetal inferior, las separaciones entre pobres a través de las líneas trenzadas o el tipo de mesa y patas. Tal circunstancia supone un problema a la hora de datar este fragmento pictórico ya que, en primer lugar, una irregular conservación nos impide apreciar detalles determinantes y en segundo, el hecho de que se trate de una copia imprime a dicho fragmento una ausencia de identidad pictórica propia. Además, las inscripciones tampoco aportan algún dato significativo que, apoyado por la documentación, pudiera ofrecernos alguna conclusión al respecto. Así pues, y después de todo lo dicho, se podría datar este fragmento pictórico, con reservas, hacia finales del siglo XIV ya que su estilo pictórico refleja ciertos paralelismos lejanos con los vistos en lo figurado en la zona inferior del panel número 1.

En la zona izquierda del registro superior del panel con número de inventario 1 (Fig. 12) vemos tan sólo restos de una inscripción ${ }^{72}$. En cambio, en la parte derecha sí se ha conservado superficie pictórica, representándose tres personajes sentados bajo arcos escarzanos, que se apoyan en pinjantes entre cada personaje y decorados en su intradós con una tracería de trilóbulos y pinjantes. En las enjutas se situaron pequeñas rosas que se desarrollan en tres pétalos afilados. De las tres figuras la mejor conservada es la central y observando las partes que aún restan de las otras dos pue-

\footnotetext{
${ }^{72}$ Totalmente ilegible por el deterioro, tan sólo algunas letras pueden entenderse.
}

de afirmarse que el tipo de figuración de todas ellas es la misma. Se disponen sobre un fondo monocromo de color rojo y visten túnica larga, de la que asoman los pies, una especie de manto con aberturas en los lados por donde salen los brazos y, sobre los hombros, una capa. Van tocados con un bonete negro y sostienen en las manos libros abiertos, en una actitud de lectura. Sobre estas figuras quedan restos de una inscripción casi ilegible por restar solamente la parte inferior de ella. De hecho, de entenderse algo sería en romance, cuestión que difiere con la general redacción del resto de los epígrafes en latín. Tanto los pliegues, más serenos y menos incisivos, como el tipo de arcos trilobulados representados, así como el carácter de letra nos llevarían a pensar que estamos ante una ejecución pictórica del siglo $\mathrm{XV}$, quizás hacia la mitad de éste, aunque es complicado precisar una cronología debido a los escasos parámetros con los que contamos para tal labor.

El pequeño fragmento conservado, correspondiente con el número de inventario 4 (Fig. 8), muestra una composición en consonancia con las anteriores, ya que se representó una mesa con mantel sobre la que se disponen panes redondos, jarras y cuencos. A ella se sientan varios comensales -de los que vemos dos casi en su totalidad y parte de otros dos en los extremos- para recibir el óbolo diario. Esta vez sí vemos sus pies bajo la mesa y una escena anecdótica, en un primer plano, en la que se produce una pelea entre un gato y un perro. Seguimos encontrándonos con la misma idea de cobijamiento de los personajes a través de arcos escarzanos, apoyados en esta ocasión en columnas. Probablemente, en la parte superior y a tenor de lo visto hasta el momento hubo inscripciones, aunque la pérdida de la pintura en dicha zona impide afirmarlo categóricamente. Ofrecer una datación para este fragmento sigue planteando ciertas complicaciones, debido a que 
no disponemos, dado el reducido espacio pictórico, de muchos elementos que poder conjugar para el análisis cronológico. Contamos con pliegues en las vestimentas más naturales que algunos de los vistos hasta el momento y con arcos ausentes ya de tracerías, pero el hecho de que sigamos estando ante una ejecución que copia, en parte, la composición y algunos de sus elementos jarras, panes- de otros fragmentos, llevaría sin embargo a dotarle de una fecha de ejecución anterior a la real. En todo caso, y sin carácter determinante, este fragmento podría ubicarse en la segunda mitad del siglo $\mathrm{XV}$, quizás más cercano a los años finales de dicha centuria.

Estamos ahora ante el panel correspondiente al número de inventario 6 (Fig. 9). La zona superior se encuentra muy dañada, de manera que se han perdido las inscripciones que, en este caso, sabemos afirmativamente que hubo, ya que resta una escasísima muestra de ello en la zona izquierda. Una vez más, la composición se estructura a través de una larga mesa, sin mantel y con los alimentos sobre ella. Debajo vemos los pies de los ocho personajes -en este caso femeninos-, tres de los cuales llevan niños en sus brazos. Ya no se separa a los comensales por grupos, según el número de pobres fundados, sino que esta escena presenta una composición corrida con todos los personajes. Parte de esta impresión se debe a la integración del grupo de comensales en un espacio abovedado, sostenido sobre una serie de ménsulas que articulan la composición, representándose también el muro del fondo dividido en dos alturas: la parte inferior refleja el paramento de sillería, en tanto que la superior, receptora del abovedamiento, presenta lo que podría ser un estucado de color rojizo, separada de la inferior por medio de una cenefa de arcuaciones. La bóveda que parece representarse es de terceletes, según nos indicaría el haz de nervaturas que descansa sobre cada ménsula. Volvemos a ver tam- bién la escena del perro y del gato en un primer plano de la composición, aunque esta vez separados. Por lo que atañe a la cronología éste fragmento parece ser el más tardío de todos. La composición estructurada a través de la mesa sigue siendo la misma, aunque encontramos elementos que, tal y como se verá en páginas posteriores, indican una ejecución pictórica más cercana a nosotros. Veremos cómo el tipo de personajes representados corresponden a una nueva mentalidad caritativa en la institución de la Almoina leridana, así como el hecho de que ya no se separen por grupos de pobres. Así, el estilo pictórico y el tipo de abovedamiento representado propio del cambio de centuria, llevan a pensar en el siglo XVI -la primera mitad- como momento en el que se realizó este fragmento pictórico.

Por último cabría hablar del panel con número de inventario 5 (Fig. 13). Al respecto poco puede decirse ya que prácticamente es inexistente. Vemos tan sólo parte de la habitual cenefa trenzada y una mano cogiendo un trozo de pan de los que hay en la mesa, junto a una jarra. Por esta razón es imposible hacer un análisis exhaustivo, aunque la línea trenzada de separación y el jarro y panes alargados se pueden poner en paralelo con los elementos análogos, vistos en el panel con número de inventario 2 y la parte inferior del 1. Podría plantearse entonces que este pequeño fragmento perteneciera a una de esas dos campañas pictóricas, o bien que se trate de una copia, realizada en un momento indeterminado posterior a la ejecución de las citadas, tomándolas como muestra; costumbre figurativa que, ya hemos ido comprobando, fue habitual en las pinturas de la Pia Almoina. En todo caso, lo poco que podemos ver en este fragmento nos permite imaginar una composición pareja a las vistas hasta el momento, articulada a través de una larga mesa con los alimentos, tras la 
que se disponen los pobres asistentes al reparto de la limosna ${ }^{73}$.

No sabemos hasta qué momento se estuvo pintando en los muros de la Almoina a los pobres que se alimentaba, aunque no debió perdurar mucho más en el tiempo ya que, en fechas inciertas entre los siglos XVI y XVII, se realizaron obras en el edificio de la canónica y se taparon con yesos las pinturas que aquí estamos tratando, saliendo a la luz a mediados de la pasada centuria, tal y como se ha referenciado al comienzo de estas páginas.

\section{INTERPRETACIÓN ICONOGRÁFI- CA DE LAS PINTURAS DE LA 'PIA ALMOINA' DE LLEIDA}

El espacio arquitectónico destinado en las catedrales a refectorio de pobres conllevó una decoración figurada que, en la gran mayoría, representa una temática religiosa basada en episodios del Antiguo o del Nuevo Testamento, pero que en algunos casos muestra una clara identidad iconográfica con el espacio al que se circunscri$\mathrm{be}^{74}$. Existen ejemplos textuales y artísticos que nos muestran, ya desde antiguo, una tradición ornamental en este tipo de espacios eclesiásticos. Incluso se conservan carmina que dan prueba de ello, como es el caso del compuesto por Alcuino para el refectorio de Nouaillé, en cuyos versos podemos leer Pauperibus tribuens panes partemque ciborum, o del titulado Ad mensam donde se nos refiere la decoración de un comedor anónimo donde se figuró la Caída del Maná, Moisés haciendo brotar agua de la roca, la Multiplicación de los panes y los

$$
\text { - }
$$

${ }^{73}$ Decir aquí que las recientes restauraciones en la canónica ilerdense han sacado a la luz restos de pintura de la almoina en la zona noroccidental del refectorio, sin que podamos decir mucho más al respecto.

${ }^{74}$ G. FERNÁNDEZ SOMOZA, "Iconografía y funcionalidad arquitectónica en la pintura de las Limosnas catedralícias en la Corona de Aragón”, op. cit. peces y el Milagro de la transformación del agua en vino ${ }^{75}$. Tenemos el testimonio de Jacques d'Amboise sobre el programa pictórico para el refectorio que se edificó a finales del siglo XI en Cluny: Ista domus refectorii habetur gloriosa in picturis tam nivi quam veteris Testamenti, principum fundatorum et benefactorum coenobii Cluniacensis cum immensa imagine Christi, et repraesentatione magni ipsius iudicii: In quo scribuntur versus qui sequuntur. Ecce dies magnus, quo iudex praesidet agnus / Sponte, vel ingratum cui subditur omne creatum: / Infelix vere, cui non datur ista temere / Nam praesens ignis domus est aeterna malignis, / Deo gratias $^{76}$. El programa pictórico cluniacense serviría como base para decorar otros refectorios monásticos, como es el caso del de la abadía italiana de Nonantola ${ }^{77}$.

No son muchos los ejemplos que han llegado a nosotros pero sí suficientes para considerar viable la existencia de determinados temas iconográficos cristológicos vinculados a dicho espacio como son la Crucifixión, la Última Cena, o los Milagros de los panes y peces y de la conversión del agua en vino, como acabamos de ver. Luego, también existen otros que manifiestan una decoración figurativa totalmente ligada a la funcionalidad del lugar, siendo este el caso de Lleida o bien el de la catedral francesa de Viviers, donde además de escenas profanas, ornamentación vegetal, geométrica y animalística y una Crucifixión sobre el muro norte, nos encontramos, en las cuatro enjutas del arco diafragma que divide la estancia, representaciones de personajes con alimentos y bebidas (Fig. 14). En uno de los lados del arco aparecen dos figuras

\footnotetext{
75 C. SEgRe MONTEl y F. ZULIANi, La pittura nell'Abbazia di Nonantola. Un refettorio affrescato di età romanica, Nonantola, Comune di Nonantola, 1991, pp. 29-30, nota 4

${ }^{76}$ Ibid., p. 32.

77 Ibid., pp. 99-102.
} 
afrontadas -una femenina y la otra masculina-, portando la primera de ellas una jarra y una copa, mientras el segundo personaje se lleva a la boca una gran cuchara con alimento. En la otra cara del arco sólo se conserva la imagen de un hombre que sustenta con su mano derecha un pan redon$\mathrm{do}^{78}$.

Otra de las constantes representativas vinculadas a los espacios eclesiales que estamos tratanto es la Crucifixión de Cristo. Contamos para el caso con los ejemplos franceses de la catedral de Arles y de la de Lyon, donde existe una interpretación iconográfica para el refectorio de la primera, basado en los fragmentos pictóricos, y una constancia documental para el de Lyon, a través de un obituario de la catedral donde se manifiesta que Guillaume Talons, portitor del refectorio mandó pintar un crucifijo en el muro oriental ...ante crucifixum quem cum toto pariete orientali idem Willelmus preciosis decoravit picturis ${ }^{79}$.

En la Península hallamos también esta misma iconografía en el refectorio de la catedral de Pamplona (Museo de Navarra). Los fragmentos pictóricos relativos a dicha estancia catedralicia plantean interesantes cuestiones desde diversos puntos de vista ${ }^{80}$. En la puerta de entrada a esta dependencia, desde el exterior, apreciamos una representación escultórica de la Última Cena, mien-

\footnotetext{
${ }^{78}$ Estas pinturas fueron restauradas en 1975 tras su redescubrimiento -ya que se conocía su existencia desde el siglo pasado- y se han datado en torno al segundo cuarto del siglo XIV (Y. ESQUIEU, Autour de nos cathédrales. Quartiers canoniaux du sillon rhodanien et du litoral méditerranéen, París, 1992, pp. 207-209).

${ }^{79}$ Ibid., pp. 206-207, nota 94.

${ }^{80}$ Entre ellos el conocimiento de la autoría de los frescos por el pintor Juan Oliver, así como la fecha de su realización en 1335. (M. C. LACARRA DUCAY, Aportación al estudio de la pintura mural gótica en Navarra, Pamplona, 1974, pp. 155-206; J. MARTínEZ DE AGUIRRE y F. MENÉndeZ PIDAL, Emblemas heráldicos en el arte medieval navarro, Pamplona, 1996).
}

tras en el interior se desarrolló, en el muro del testero y en la puerta de acceso al púlpito ${ }^{81}$, una gran representación pictórica $-6,15$ m. de altura por 3,76 de anchura- que nos narra momentos de la Pasión de Cristo, desde la Flagelación hasta la Resurrección (Fig. 15). Son cinco las escenas estructuradas en tres registros horizontales, de los que el central se compone solamente por la Crucifixión. Bordeando la composición pictórica se dispusieron figuras de profetas del Antiguo y Nuevo Testamento en los lados, mientra la zona inferior se reservó para la figuración de juglares entre los escudos de quienes encargaron la obra ${ }^{82}$. Ya finalmente, se pintó un último registro donde una inscripción nos proporciona la fecha de ejecución de las pinturas, del promotor y del artista ${ }^{83}$.

También sobre la puerta del refectorio de la Catedral de Valencia había en época medieval una tabla pintada donde se representó a los pobres en la Almoina. La obra artística no se ha conservado, así que sabemos de ella a través del contrato entre

\footnotetext{
${ }^{81}$ En este último lugar el mismo Juan Oliver pintó una cabeza de Cristo en el tímpano de la puerta, hoy también custodiada en el Museo de Navarra.

${ }^{82}$ De izquierda a derecha nos encontramos con el escudo de D. Árnaldo de Barbazán, obispo de Pamplona; el de los reyes de Navarra, Juana II y Felipe de Evreux (1328-1349); con el de Gastón II, conde de Foix y Vizconde de Béarn (1319-1343), y por último, con el de D. Miguel Sánchez de Asiain, arcediano de la tabla en la catedral (M. C. LACARRA DUCAY, Aportación al estudio de la pintura... op. cit., pp. 155-206; J. MARTínEZ DE AGUiRRE y F. MENÉNDEZ PIDAL, Emblemas heráldicos en el arte medieval navarro, op. cit.)

${ }^{83}$ ANNO D[OMI]NI M CCC XXX: E VO DOMINUS IO[H]A[N]NES PETRI DE STELLA: ARCHIDIACONUS S[AN]C[T]I PETRI DE OSUN FUIT OPERARIUS E[C]CL[ES]IE B[E]ATE S[ANCTE] M[ARIE] PAMIL[O]N[ENSIS] FECIT FIERI ISTUD REFERTORIU[M] ET IOHANNES OLIVERI DEPINXIT ISTUD OPUS (J. MARTíneZ de AgUiRRe y F. MENÉNDEZ PidAL, Emblemas heráldicos en el arte medieval navarro, op. cit., p. 274)
} 
el cabildo catedralicio y el pintor Jaume Baçó -fechado el 31 de marzo de 1441- y en el cual se especificaba que se debían pintar, entre otros, a los pobres, a un canónigo dando la limosna y al obispo: Capitols fets e fermats entre lo honrat mossen Andreu Garcia prevere beneficiat en la Seu de Valencia per lo honorable capitol de aquella a aço specialment deputat e en Jacomart bacort pintor sobre una taula la qual ha star damunt lo portal de la almoyna de la dita seu. -Primerament que ell pintara la dita taula en la qual haia tants pobres com pintar si poran seiguts en una taula ab hun canonge que dona la almoyna ab lo capella $e$ bedell e un servidor e lo bisbe que seu al cap de la taula ab una cadira en pontifical acabant de bones colors al mils que pora. $(. . .)^{84}$.

De igual modo, y siguiendo en los reinos hispanos, cabe destacar la tabla pintada que había en el interior del refectorio de la Catedral de Palma de Mallorca, hoy en el Museo catedralicio. Fechada a finales del siglo XV y atribuida a Joan Desí, muestra una composición a través de una larga mesa con Cristo sentado en el centro y flanqueado por cuatro personajes -dos hombres y dos mujeres- que reciben la refacción en forma de monedas por dos canónigos, situados en los extremos de dicha mesa (Fig. 16). En la zona inferior se sitúan una serie de escudos que corresponden a familias locales, como fueron los Santacília, los Ferrandis, los Verí, los Dameto, los Roig y los Gual; mientras en la zona superior una inscripción reza: QUOD UNI EX MINIMIS MEIS FECISTIS MIHI FECISTIS ${ }^{85}$.

\footnotetext{
${ }^{84}$ J. SANCHÍS Y SIVERA, Pintores medievales en Valencia, Estudis Universitaris Catalans, t. VI y VII, Barcelona, 1914, reed. Valencia, 1996, pp. 81-82.

${ }^{85}$ G. LLOMPART, La pintura medieval mallorquina. $\mathrm{Su}$ entorno cultural y su iconografía, Palma de Mallorca, 1977-1980, vol. III, pp. 184-185, denominado entonces Maestro de San Francisco; Id., "Joan Desí. Taula de l'Almoina", Mallorca Gótica, 1998, pp. 217-218. Esta inscripción corresponde al Evangelio de Mateo (25, 34-
}

De la Almoina de la Catedral de Barcelona resta solamente el testimonio de lo que hubo, gracias a una cromolitografía de Jaime Serra, realizada a mediados del siglo XIX y que nos permite ver la decoración pictórica que tuvo el refectorio de los pobres de dicha catedral. Tan sólo sobrevivió parte de la pintura de uno de los muros sus medidas eran $2,30 \mathrm{~m}$. de alto por $4 \mathrm{~m}$. de ancho- aunque parece ser que todos estuvieron decorados con frescos (Fig. 17). En la acuarela realizada por Serra observamos una larga mesa alrededor de la cual se sientan los pobres de la Almoina. Incluyendo a dos sirvientes, contamos trece personajes entre los que nos encontramos con hombres jóvenes, maduros, ancianos y mujeres -una de ellas con un niño- ${ }^{86}$.

Llegado este punto quizás debiera citarse un ejemplo que de algún modo podría ponerse en paralelo con lo que aquí estudiamos. Me refiero a las ménsulas esculpidas del refectorio del Palacio Arzobispal de Santiago de Compostela. En ellas vemos representaciones de banquetes aunque, en este caso, no se trata de la comida caritativa dada a los pobres, sino de la imagen tallada del ágape vinculado a ceremonias de la nobleza, propias del comedor de un palacio arzobispal $^{87}$. La Historia Compostelana narra

40), cuando narra el Juicio Final en el que el Señor hará distinción entre los merecedores de salvación eterna y los condenados.

${ }^{86}$ La cronología de estas pinturas se ha puesto a finales del siglo XV (P. DE MADRAZO, "Pintura mural en la Almoyna de Barcelona", Museo Español de Antigüedades, t. V, 1875, pp. 93-108; S. SANPERE Y MiQUEL, Los cuatrocentistas catalanes. Historia de la pintura en Cataluña en el siglo XV, t. II, Barcelona, 1906, pp. 189195).

${ }^{87}$ Lo que vemos representado en este espacio es una lección figurativa de cómo debían realizarse dichas ceremonias, inspirada en la legislación alfonsí al efecto (M. NúÑEZ RodríGueZ, El Refectorio del Palacio de Gelmírez. El espejo moral de un espacio para 'yantar', Santiago de Compostela, 1996). 
cómo el arzobispo de Compostela, Diego Gelmírez, construyó el palacio adecuado e incluso propio de un rey como correspondía a un arzobispo de Santiago y legado de la Santa Iglesia Romana, para dar acogida a los miembros de la nobleza y realeza que acudían a Santiago como peregrinos ${ }^{88}$. Éste es, por tanto, un lugar donde también se dio de comer a los peregrinos que acudieron a Santiago, aunque la categoría social de dichos visitantes distó mucho de la de aquellos romeros que vemos representados en las pinturas de la Pia Almoina de Lleida.

De igual manera, otras obras artísticas fueron susceptibles de albergar la representación iconográfica de la limosna a los pobres. Así sucede con los sepulcros. Gracias al fuerte arraigo que tuvo en la Edad Media la caridad como medio de salvación del alma, encontramos numerosas mandas testamentarias en las que se dona parte de los bienes a los necesitados, además de ofrecer la denominada pitanza a los pobres en el día de la sepultura ${ }^{89}$. Este hecho se plasmó artísticamente en algunos sepulcros góticos, entre los que destacan los de los obispos D. Martín II Rodríguez y D. Rodrigo II Álvarez, ambos en la catedral de León ${ }^{90}$. En el frente de su yacija se represen-

${ }^{88}$ Historia Compostelana, ed. E. Falque Rey, Madrid, 1994, p. 345.

${ }^{89}$ Existe una constitución capitular en Lleida, del año 1363, por la que el obispo Romeo Cescomes regulaba este hecho y más en concreto las refacciones funerarias facta super sepulturis (A.C.L., Constitutiones Ecclesiae Cathedrali Ilerdensis, cajón 218, fol. 35r.-v.).

${ }^{90}$ Sobre la liturgia de los funerales y su representación en la escultura castellano-leonesa de la época, incluyendo la pitanza a los pobres, vid. J. YARZA LUACES, "Despesas fazen los omnes de muchas guisas en soterrar los muertos", Fragmentos, no 2 (1984), pp. 4-19; M. J. GÓMEZ BÁRCENA, "La liturgia de los funerales y su repercusión en la escultura gótica funeraria en Castilla", en La idea y el sentimiento de la muerte en la historia y en el arte de la Edad Media. Ciclo de conferencias celebrado del 1 al 5 de diciembre de 1986, coord. M. Núñez y E. Portela, Santiago de Compostela, 1988, pp. 31-50, tó la pitança de aniversarios. Esto es, con motivo de la celebración del funeral unos sirvientes, desde la puerta del palacio episcopal leonés, distribuyen panes y alimentos a un grupo de pobres, tullidos, enfermos y peregrinos $^{91}$.

Volviendo nuevamente a la Almoina, $\mathrm{y}$ tras lo expuesto, parece claro establecer una iconografía para estos espacios; iconografía que muestra una estrecha consonancia con la actividad que en ellos se desarro1 ló $^{92}$. Así, al igual que en otras Almoinas catedralicias y en sepulcros, como acabamos de ver, en el refectorio de Lleida existió una iconografía estipulada en todos sus fragmentos pictóricos, de manera que aún correspondiendo éstos a diversos momentos cronológicos a lo largo de la Edad Media y los inicios de la Moderna, siguen presentando un mismo modelo compositivo. A lo largo de todos estos siglos se produjeron cambios institucionales que no se vieron

especialmente, pp. 49-50; R. SÁNCHEZ AMEIJEIRAS, Investigaciones Iconográficas sobre la escultura funeraria del siglo XIII en Castilla y León, Tesis doctoral en microficha, Universidad de Santiago de Compostela, 1994, pp. 60 y 80; Id., "Dos ejemplos de patronazgo en la iconografía de la escultura funeraria gótica leonesa", en Actas VII Congreso Español de Historia del Arte, Murcia, 1988, Patronos, promotores, mecenas y clientes, Murcia, 1992, pp. 81-86, en particular, pp. 83-85; A. FRANCO MATA, Escultura gótica en León y provincia (12301530), León, 1998, pp. 384-391.

${ }^{91}$ Existía además el hábito de fundar porciones de pobres para el día del aniversario de la muerte del fundador. En Lleida, y gracias a la información que nos da un manuscrito fechado en 1330 sobre la asignación de censales para los pobres de la Almoina, sabemos que hubo en total 386 pobres extraordinarios comiendo en el refectorio el día del aniversario de sus respectivos fundadores (P. SANAHUJA, Historia de la beneficencia... op. cit., pp. 84-85). Sobre el tema vide también P.-A. FEVRIER, "À propos du repas funéraire, culte et sociabilité", Cahiers Archéologiques, 26, (1977), pp. $29-45$

92 G. FERNÁNDEZ SOMOZA, “Iconografía y funcionalidad arquitectónica en la pintura de las Limosnas catedralícias en la Corona de Aragón", op. cit. 
reflejados en sus pinturas. Un ejemplo lo tenemos en el cambio producido en el refectorio leridano a mediados del siglo XIV en el que se sustituyó la comida dada por una cuantía en monedas. En la tabla procedente de la Catedral de Mallorca, sin embargo, sí se figuró la entrega de las monedas diarias a los pobres.

Otro cambio producido en la cotidianeidad caritativa que, esta vez sí, se plasmó pictóricamente en las pinturas de la $\mathrm{Seu}$ Vella es el hecho de que, a partir del siglo $\mathrm{XV}$, las fundaciones de pobres fueran cada vez menores y por el contrario aumentaran los beneficiados colectivos como hospitales o comunidades religiosas. Era igualmente una forma de caridad y de cumplir con las leyes cristianas y eclesiásticas, razón por la cual se manifestó plásticamente en los muros de la Pia Almoina. El panel con número de inventario 6 refleja una larga mesa con unos comensales muy particulares: todos son mujeres. Dos de ellas llevan hábitos y otras dos cargan en sus respectivos regazos sendos niños, mientras una tercera, sin que pueda afirmarse por los daños que sufre la pintura, parece también tener entre sus brazos una criatura. Una de las monjas, además, se encuentra sirviendo a una de las mujeres con niño, mientras el resto de los personajes femeninos comen de los alimentos que se encuentran en la mesa. Se trata, pues, de una representación de la caridad que ofrecía la Almoina a uno de los hospitales, quizá el Hospital General, el Hospital de los Pobres Huérfanos, o bien el convento de Santa Clara, a los que dicha institución otorgó ayudas económicas ${ }^{93}$. La limosna a

-

${ }^{93}$ En el siglo XIV se documentan, al menos, dos donaciones al Convento de Santa Clara de Lleida. La primera de ellas corresponde al año 1338, en el que se dio una libra y media de carne de cordero casi todos los días del mes de diciembre, además de otros días con anterioridad a este mes. La segunda se ubica a finales de siglo, en 1399, cuando Berenguer Gallart, ciudadano de Lleida, legó, en su testamento, cien estas instituciones benéficas era algo común en la época, reflejado también en los sermones. El mismo Vicente Ferrer en uno de ellos decía que la limosna había que ofrecerla singularment a orphanes e fadrines pobres a maridar e ospitals a mantenir ${ }^{94}$. Sabemos además, gracias a la documentación, que la Almoina leridana se preocupó por los huérfanos y por estas doncellas pobres. A modo de ejemplo citar tan sólo una breve muestra de noticias, de las que la primera se refiere a la donación en 1330, por parte de Pere de Cervyllés, de varias porciones a la Almoina con la finalidad de que fueran repartidas entre pobres vergonzantes y huérfanos de todas las parroquias leridanas ${ }^{95}$. La segunda corresponde a tres porciones claustrales

sueldos anuales para obras en el monasterio de Santa Clara, y ropas para vestir cada año a tres religiosas del convento (P. SANAHUJA, Historia de la beneficencia... op. cit., pp. 168 y 86-87, respectivamente). Pasado el tiempo, ya en 1574, la Pia Almoina ayudó a la comunidad del monasterio de Santa Clara en las obras del convento. Tres años más tarde, la misma Almoina les consiguió una cantidad de cuatro cahices de harina; en 1587 se les dio dinero para arreglar el órgano de la iglesia, y para obras de caridad algo más tarde, en 1590. Durante el siglo XVII estas ayudas al monasterio siguieron tanto por parte de la Pia Almoina como por parte de los Pahers del Ayuntamiento (J. MATEU IBARS, "El monasterio de Santa Clara de Lleida. Notas para su historia", en Las clarisas en España y Portugal. Congreso Internacional, Salamanca, 20-25 sept., 1993, Actas II, vol. I, Madrid, 1994, pp. 945-968, en especial p. 948).

${ }^{94}$ V. FERRER, Sermons, vol. I, Barcelona, 1932, p. 187. El hecho de que la burgalesa Elvira González, declarando en su testamento heredero universal al Hospital de Santa María la Real de Burgos en 1341, estableciese el tipo de gente que podía concurrir a dicha institución, prohibiendo que cogan muger que sea uellaca nin que traia fiio en braços nin muger preniada saluo ende romeras de camino (publ. L. MARTíNEZ GARCÍA, La asistencia a los pobres en Burgos en la baja Edad Media. El Hospital de Santa María la Real 1341-1500, Burgos, 1981, p. 45) manifiesta el hábito que por aquel entonces existió de albergar a este tipo de personas en los hospitales.

${ }^{95}$ P. SANAHUJA, Historia de la beneficencia... op. cit., p. 82 . 
extraordinarias dadas en 1524 por el Cabildo a través del administrador de la Almoina, una a la hija de la viuda Martina y dos a la hija del panadero de la Suda, en ambos casos como dote para el matrimonio ${ }^{96}$. Y una última noticia al respecto fechada en 1530, en la que Lope de Arrúe, maestro de obra de la Seu, hacía una donación a través de la Pia Almoina para las doncellas pobres $^{97}$. Quizás algunas de las mujeres que aparecen en las pinturas -en los paneles con número de inventario 3 y 6- sean una representación de estas doncellas carentes de dotes para casarse, bien debido a su horfandaz o bien debido a la pobreza fami$\operatorname{liar}^{98}$. Las tres mujeres que, en el fragmento correspondiente al número 6, aparecen con niños en sus regazos podrían tratarse de nodrizas, ya que tenemos constancia de la existencia de estos personajes para criar a los niños dejados a cargo de los hospitales o bien en casas particulares ${ }^{99}$. En 1397 la Almoina de Lleida dio trescientos cinco suel-

-

96 Ibid., p. 146.

${ }^{97}$ G. ALONSO GARCÍA, Los maestros de la 'Seu Vella de Lleida' y sus colaboradoes, Lleida, 1976, p. 235.

98 Para sufragar dicha situación, a finales de la Edad Media, las diferentes instituciones benéficas entre ellas los hospitales- o bien personajes particulares daban limosnas. Véase al respecto T. M. VINYOLES I VIDAL, "Ajudes a donzelles pobres a maridar", La pobreza y la asistencia a los pobres en la Cataluña Medieval, Barcelona, 1980, pp. 295-362.

${ }^{99}$ Existe documentación muy elocuente al respecto, como la noticia de 1383 que recoge M. T. Vinyoles referente al hospital de Sant Macià -en Barcelona- y nos habla del abandono de una niña a las puertas de dicho hospital: hic fou posada una infanta en una senaya $a b$ alcuns drapiyols e ab I flori e ab I albarà...e aquest dia matex comena-la a na Graula aletar a I mes, qui està detràs los frares del sach, doli-n XXX sous del més e un quarteró d'oli. L'alberà inclòs solt diu: "Jesus. Al procurador del espital rebets aquesta infants e fets que aya bon recapte de nodryrla, pus dedeu bon maryt...l'infanta es qrestiana a nom Antònia" (J. M. RocA, El bressol de l'hospital de la Santa Creu, Barcelona, Anuario del Hospital de la Santa Cruz, 1921-22, según T. M. VINYOLES I VIDAL, “Ajudes a donzelles pobres a maridar", op. cit., p. 318). dos y un dinero para la manutención y el calzado de dos niños huérfanos que habían sido dejados al custodio de sendas nodrizas, en sus respectivas casas, haciéndose cargo la misma institución de todo el gasto que dichas criaturas hiciesen. Pocos años después, en 1409, pagó otros cuatrocientos ochenta y cuatro sueldos y dos dineros por tres niños expósitos que se encontraban bajo la protección de la Almoina, tras haberlos encontrado abandonados en la catedral. Los dejaron en casas particulares para que fuesen criados, y la Almoina corría con los gastos de alimentación, vestido y calzado $^{100}$. Quizás en este mismo sentido haya que interpretar la representación de la mujer con el niño sentada a la mesa que veíamos en la pintura de la Almoina de Barcelona. Estamos, de todos modos, ante la imagen plástica de la caridad ejercida por la Pia Almoina, siendo los frescos del refectorio de la Seu Vella leridana un documento gráfico de la realidad del momento, manifiesta, en el siglo XVI, en la caridad a otras instituciones benéficas como las ya mencionadas líneas arriba: hospitales de huérfanos y comunidades religiosas.

Por otro lado, las inscripciones con el nombre de los fundadores y el número de pobres a instituir en los muros del refectorio leridano podría parecer en cierta medida algo peculiar, pero sin embargo se trata de un hábito común en estas dependencias catedralicias. Estos "letreros" eran útiles a los administradores y futuros beneficiarios, ya que daban a conocer las condiciones exigidas en cada caso -según los tipos de pobres-. Además, tal y como nos lo atestigua una Constitución capitular de 1367, bajo el título De presentatione pauperis claustri, el nombre del fundador en el muro servía para designar el lugar del comedor que debía ocupar cada uno de los pobres, y p. 169.
} 
evitar así discusiones o peleas por situarse en unas $\mathrm{u}$ otras plazas: Postremo ordinamus que procurator domini episcopi et canonici ecclesie ilerdensis pauperes quos secundum ipsius ecclesie ordinationis ponunt seu mittunt in claustro procuratoribus elemosine dicte sedis ante quem introducantur presentare teneantur et que dicti procuratores sedem eorum bonam conscienciam eos admitant ut omnis fraudis materia evitetur ${ }^{101}$. Así pues este hecho explicaría por qué, cuando el arcediano de Benasque Capdevila Calvó legó en su testamento -con fecha 5 de septiembre de 1386- parte de sus bienes a los pobres del claustro de la $\mathrm{Seu}$, para que instituyesen con ellos a cuantos pobres fuese posible, especificó que los predichos pobres sean pintados en la pared según es costumbre hacerlo ${ }^{102}$. De igual modo se explica que en 1457 se tomasen ante notario el nombre de los fundadores y sus armas para, tras la obra realizada, ser copiados de nuevo ${ }^{103}$. También esto ocurrió en la Almoina de Barcelona, donde tenemos la constancia documental a través del Kalendari de òbits i pabordes, que nos narra idéntica finalidad de las inscripciones de los fundadores en las paredes del refectorio que la que acabamos de ver para la Almoina leridana ${ }^{104}$. En el testimonio plástico conservado, gracias a la acuarela realizada por J. Serra, podemos ver bajo las pinturas los nombres de los fundadores con el número de pobres instituidos y la especificación de la perpetuidad o temporalidad de la porción, entendiendo por I Almoyna una porción perpetua u ordinaria, y por $V$

\footnotetext{
101 A.C.L., Constitutiones Ecclesiae Cathedrali Ilerdensis, cajón 218, fol. 51r.-v.

${ }^{102}$ P. SANAHUJA, Historia de la beneficencia..., op. cit., pp. 61-62.

103 A.C.L., Manuale Deliberationum...Capituli, años 1457-1467, n. 91, fol. 7 v., según P. SANAHUJA, Historia de la beneficencia... op. cit., p. 62, nota núm. 28. Vid. nota 63 .

104 J. BAUCELls I ReIG, "Gènesi de la Pia Almoina de la Seu de Barcelona..." op. cit., p. 58.
}

mesos o I dies, una extraordinaria, referida al tiempo indicado: PE EN PER GOMES, I ALMOYNA.-ALTRES, V MESOS.-PER MOSEN PERE POQUET, I ALMOYNA.-PE EN PERE MOLINER BASTAX, I ALMOYNA.-PER NA BLANCA DE FRIAS, II ALMOYNAS.-PER EN FRANCESCH DE FOX...-PER EN GUILLEM PONS DE FONOLLET, MERCADER, I ALMOYNA.DEN MOYOL, I DIES.-PER NA DOLSA DE PUIGVENTOS, I ALMOYNA.-PER LA SENYORA... III... ${ }^{105}$.

Recordemos que durante el siglo XIV y parte del $\mathrm{XV}$, el refectorio leridano daba acogida a los pobres receptores de la limosna, pero no era un lugar de pública entrada, razón que desestima la idea de propaganda de dichas inscripciones. Con esta última finalidad ya se encontraban los epitafios de las lápidas, donde se alababa la bondad y caridad del difunto explicitando las fundaciones de pobres realizadas en vida. Pasado el tiempo -en 1477- el espacio de la Almoina fue cedido a la Cofradía de San Salvador o de los Clérigos Pobres, momento a partir del cual se convirtió en un lugar de posible acceso a la gente, dado que en él se realizaban misas diarias. Uno de los paneles pictóricos de la Pia Almoina -número 6- se ha situado en estas páginas, con posterioridad cronológica a estas fechas. Evidentemente este fragmento pictórico no refleja ya la situación a ocupar por los diferentes pobres que recibían la limosna diaria en dicho espacio. Estas pinturas se realizaron, en cambio, siguiendo una tradición plástica presente durante toda la Edad Media, y con una voluntad de perpetuar el hábito cristiano de la caridad a los más necesitados de la sociedad, al mismo tiempo que se proponía una forma de redimir el alma E prench de mos bens pro anima mia vint lliures reyals de Valencia (...) e daltres obres pies en suffragi de

${ }^{105}$ P. DE MADRAZO, "Pintura mural en la Almoyna de Barcelona", op. cit., p. 108.
} 
la mia anima ${ }^{106}$. Cuestión a la que se responde de manera muy concluyente en la Vida de San Eloy: Potuit nemque Deus ommes homines divites facere, sed pauperes ideo in hoc mundo esse voluit, ut divites haberent quomodo peccata sua redimerent ${ }^{107}$. Debido a esto, dicho panel pictórico no se fraccionó compositivamente en grupos de pobres con inscripciones identificativas del carácter de su refacción, ya que para entonces no existía el comedor de la Almoina como tal, siendo por tanto innecesario determinar el lugar de los pobres dentro del refectorio.

A excepción de este último panel, el resto de ellos siguen un mismo esquema compositivo en el que vemos una larga mesa con grupos reducidos de pobres separados por cenefas y bajo arcadas. Esta costumbre debida, como acabamos de ver, a facilitar la ubicación de los beneficiados en sus respectivos lugares, se mantuvo durante todo el Medievo de manera que, en ocasiones, más que reproducir en las nuevas pinturas un mismo esquema compositivo, se copió parte de la pintura que estaba ya realizada en los muros de la Almoina. Tal es el caso del panel con número de inventario 3. En él vemos, en su zona izquierda, la copia de lo representado en la franja inferior del panel con número de inventario 1 ; el mismo tipo de arcadas con iguales escudos en las enjutas. El resto del panel imita lo realizado en el fragmento con número de inventario 2. De igual modo se pintan el mismo tipo de arcos, decoraciones, pie de la mesa, ornamentación vegetal en la parte inferior; por no hablar de la análoga cenefa trenzada de separación existente en todos los paneles pictóricos, a excepción de los números 4 y 6 . Además, se da la circuns-

\footnotetext{
106 Testamento del siglo XV de Pere Milà (Arxiu del Palau, Lligall 361, c. 38, fol. 1v., publ. A. BORRÀs I FELIU, “L'ajuda als pobres en els testaments de Catalunya i València del segle XV", op. cit., p. 366.)

107 Patrologia Latina, op. cit., t. LXXXVII, col. 533.
}

tancia de que la ejecución del panel número 3 debió realizarla un pintor con escasa maestría, tal y como nos lo demuestra su mala calidad pictórica y la torpeza mimética de los elementos citados, que vemos mucho mejor resueltos en los otros paneles. Otra circunstancia que quizás habría que interpretar en este mismo sentido es el hecho ya comentado de que aparezcan dos inscripciones superpuestas en la zona inferior del panel número 1. Quizás habría que entenderlo como un cambio de fundador por alguna razón para nosotros desconocida, provocando así un cambio de inscripción en el lugar correspondiente.

a) Tipos sociales representados.

Otra de las particularidades de las pinturas leridanas de la Almoina es la muestra representativa de tipos sociales de la Edad Media. En ella vemos aparecer además del clero del cabildo menor, enfermos, tullidos, los denominados pobres vergonzantes -debido a su acerada situación de indigencia-, monjas, mujeres sirvientas, otras con hijos, doncellas casaderas, y cómo no, peregrinos -hombres y mujeres- que de paso en su romería requerían de la asistencia piadosa de la Almoina leridana. Faltaría solamente en este muestrario de menesterosos los cautivos; colectivo que fue también susceptible, en buena medida, de la voluntad piadosa medieval ${ }^{108}$.

Por otra parte, debo detenerme en otros personajes de muy distinto jaez, que también fueron representados en estas pinturas y que necesitaron de la beneficencia de la Almoina, como es el caso de los doctores del Estudi General. Me refiero a las tres figuras masculinas que aparecen en la parte superior del panel con número de inventa-

\footnotetext{
108 A. BORRÀs I FELIU, “L'ajuda als pobres en els testaments de Catalunya i València del segle XV", op. cit.
} 
rio 1 . Su atuendo, así como su actitud me hace proponer que bien podrían tratarse de la imagen de los catedráticos del Estudi General. No aparecen de forma individual, sino como muestra de tal institución. Las vestimentas nos dan la pauta para tal hipótesis porque, en 1447, y debido a las extravagancias en el vestir de algunos estudiantes, se determinó una norma para ataviarse con ropas apropiadas y características de tal condición. El hábito, impuesto por el obispo García Aznárez planteaba muchas semejanzas con el de los estudiantes de la Universidad de Bolonia ${ }^{109}$. La vestimenta apropiada se componía por el colobium o clotxa, que era una túnica negra abrochada por detrás, que dejaba ver los pies de los estudiantes seglares y talar para los eclesiásticos. No llevaba mangas, sino que tenía unas aberturas por donde se sacaban los brazos, viéndose así la camisa o vestido interior. Esta túnica no debía acabar en punta ni llevar el cuello adornado con sedas, bordados o puntillas. Los catedráticos, además, en señal de distinción y dignidad iban a leer con vestido talar y tocados con birrete; mientras que en los actos solemnes vestían con caperó, museta y toga, una gramalla negra parecida a la usada por los paheres en días de duelo, sin más adornos ni ornamentos ${ }^{110}$. La descripción dada de la vestimenta coincide con la representada en las pinturas leridanas. Estos personajes se figuran, además, con libros en las manos, objeto obviamente ligado a los catedráticos del Estudi General. En la aseveración de esta hipótesis nos ayuda la documentación existente sobre la conce-

${ }^{109}$ La reforma realizada por el obispo García Aznárez en 1447, bajo título Reformatio Studii Generalis Ilerdensis facta per reverendum dominum Garciam Aznares Episcopum Ilerdensis, contempló temas problemáticos entonces como la elección de doctores para las cátedras o el salario de éstos. (J. LladonOSA I PUjOL, L'Estudi General de Lleida del 1430 al 1524, Barcelona, 1970, p. 35).

${ }^{110}$ Ibid., p. 77. sión de porciones claustrales a personajes vinculados al Estudi General. Ya desde la primera mitad del siglo XV existen noticias al respecto. En una de ellas se manifiesta la costumbre del Cabildo leridano de acoger en la Almoina, tres días por semana, a tantos estudiantes como le fuese posible ${ }^{111}$. Existía además, desde el pontificado de Clemente VII (1378-1394), una bula papal que otorgaba al Estudi General parte de algunos bienes eclesiales, mayoritariamente de beneficencia, causas pías, subsidios a doncellas pobres y casaderas, etcétera. Tal sería el caso de las veinticuatro libras de pensión anual dadas por la Almoina, y destinadas al salario de los lectores bachilleres ${ }^{112}$. Otra noticia, esta vez de 1518, nos informa de la costumbre de la Almoina de dar cada año a la mencionada institución universitaria mil cuatrocientos cuarenta y cuatro sueldos $a$ los bachilleres que leen las catedrillas de cánones $y$ leyes por subvención de sus salarios 'ad beneplacitum capituli' ${ }^{113}$. Algo más tarde, en 1565 , se dieron cuatro porciones anuales a otros tantos estudiantes del Estudi Gene$\mathrm{ral}^{114}$. Por último, en 1588 , se entregaron 480 sueldos a Pedro Esteve, Doctor en derecho y depositario del Estudi General de Lleida para subvencionar de manera caritativa el salario de las lecciones dadas por Juan Dusolier, Doctor de Tolosa ${ }^{115}$. Por esta misma razón recibió Luis Fuster, Doctor en derecho y cajero de la Universidad del Estudi General, en 1594, veinticinco libras destinadas a los salarios de los catedráticos. A estos personajes se dieron ayudas para compensar el bajo estipendio de que disponían, cuestión que suscitó graves problemas al

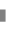

${ }^{111}$ Publ. P. SANAHUJA, Historia de la beneficencia..., op. cit., p. 175, nota 227.

112 J. LladonOSA I Pujol, L'Estudi General de Lleida..., op. cit., pp. 39 y 48.

${ }^{113}$ P. SANAHUJA, Historia de la beneficencia..., op. cit., p. 173.

${ }^{114}$ Ibid., p. 167.

${ }^{115}$ Ibid., pp. 174-175.
} 
Estudi General, ya desde la primera mitad del siglo XV, dado que dicha circunstancia hizo que muchos doctores se fuesen a otras universidades, o bien que diesen a desgana sus lecciones, cuestión que también provocó el éxodo de muchos estudiantes a otros colegios. Hasta tal punto preocupó este asunto, que en 1515 los paheres escribieron una carta al cardenal Remolins donde le hacían partícipe del problema, instándole a que otorgase alguna renta eclesial a fin de solventar el conflicto (...) Senyoria vulle favorir, consellar e endreçar a aquesta Ciutat en tot lo que per lo reverendíssim senyor Arcebisbe son germà li serà explicat, e senyaladament e precípua sobre lo dit Estudi, lo qual, Senyor, va sempre en rü̈na per la modicitat del salari dels catredans, los quals no reben sinó vint-e-tres liures quada hu, que és una misèria, de què se segueix que los dits cathredans qui forçadament se han a dimitir en advocat e en altres negocis per viure, distrahent-se del Estudi, no poden fer aquell exercici que seria mester a benefici dels studians, lo que farien si del salari de dites càtredes podien còmodament viure, car en art, Senyor, doctors hi ha qui són de tanta doctrina e tant bons lectors que si eren bé pagats no.ls farien vergonya los de Itàlia. Per ço, Senyor, volríeu trebalar en aver algunes rendes de la Sglésia per via de supressions de dignitats o beneficis, o per impòsits de pensions, o per via de applicacions, leyxes o coses pies incertes $(\ldots)^{116}$. No sabemos si esta petición trascendió favorablemente, vistas las noticias documentales anteriores en las que la Almoina contribuyó a elevar el reducido salario de los catedráticos; en todo caso es manifiesta la ayuda otorgada por la mencionada institución piadosa a los doctores del Estudi General. El carácter de dicho auxilio, destinado a aumentar el salario recibido por las lecciones en la universidad hace, seguramente, que se represente a estos personajes

\footnotetext{
${ }^{116}$ Publ. J. LladonOSA I PUJOL, L'Estudi General de Lleida..., op. cit., pp. 207-208, doc. 121.
}

con sus hábitos y libros propios de los doctores, sin figurarlos sentados a la mesa como el resto de personajes beneficiados por la Almoina, a los que sí se les daba la refacción alimenticia diaria.

El siguiente grupo social representado son las sirvientas de la Almoina. Dos de las mujeres que aparecen en la franja inferior de las pinturas con número de inventario 1 son una representación de dichas sirvientas, que atendían a los pobres en la Almoina. Una de ellas aparece con un cuchillo en la mano, mientras la otra está sirviendo bebida en una copa y charla con el monje que tiene a su lado. Las vestimentas, que no muestran signos evidentes de pobreza y, sobre todo, el hecho de que presenten una actitud servicial respecto al resto de los personajes -beneficiados de la caridad de la Almoina- me llevan a tal hipótesis. A través de la documentación sabemos de la existencia de sirvientes femeninos en la Almoina. En la Libreta de los gastos del año 1338, citada ya en páginas precedentes, además de las expensas de alimentos y del número de pobres ordinarios y extraordinarios, se habla de la gente que trabajaba en dicha institución, contando, en el mencionado año, con una cocinera, dos sirvientas y un comprador ${ }^{117}$.

En el mismo fragmento pictórico que las sirvientas aparecen dos figuras de clérigos pobres. Ambos tonsurados, con ropas clericales y comiendo, razones que no dejan lugar a dudas en la interpretación de tales personajes. Existió lo que se ha denominado un clero mayor y un clero menor. Los componentes de éste último -llamados también porcioneros- eran los personajes de la clerecía catedralicia situados en los escalafones más bajos de la jerarquía del cabildo, de tal forma que, aún ya secularizados,

${ }^{117}$ P. SANAHUJA, Historia de la beneficencia..., op. cit., p. 102. 
éstos seguían comiendo en la canónica debido a sus bajas rentas, al igual que sucedía, probablemente, con los seglares que realizaban algunas funciones de intendencia en la catedral, como porteros, jardineros o perreros ${ }^{118}$. En el fragmento de pintura con número de inventario 2 se figuró otro clérigo, con bonete, bastón y un manto con aberturas en los lados. También éste debe ser una representación de uno de los pertenecientes al clero menor, que recibían algún tipo de porción por parte del Cabildo, dada en el refectorio de la Almoina. Vemos en este mismo panel otras dos figuraciones de clérigos, que en esta ocasión sirven los alimentos a los pobres. Uno de ellos, que se figura cortando un pan, viste ropas clericales e incluso cubre su cabeza con la cogulla. Es difícil afirmarlo con tan pocos indicios, pero quizás estemos ante una representación del refector quien, como ya hemos visto en páginas precedentes, tenía entre sus tareas la distribución de las porciones a los pobres del refectorio, bajo las órdenes del limosnero o procurador mayor.

Otro tipo de pobres que aparecen en las pinturas leridanas son aquellos que corresponden a los llamados vergonzantes $\mathrm{y}$ a los enfermos y tullidos, de los que hallamos varias representaciones. En prácticamente todos los paneles aparecen figuras con muletas, signo evidente de la deficiencia física, uno de ellos con una venda en la cabeza o con ropas desgastadas y rotas, así como algunos -en el panel con número de inventario 2- con el torso descubierto y un simple manto cubriendo sus hombros. En la Edad Media todos estos atributos denotaban la condición de 'miserable', vinculada ya a la caridad ya a la condena;

\footnotetext{
${ }^{118}$ Cf. E. CARRERo SANTAMARÍA, “Ecce quam bonum et quam iocundum habitare fratres in unum. Vidas reglar y secular en las catedrales hispanas llegado el siglo XII", Anuario de Estudios Medievales, 30 / 2 (2000), pp. 757805.
}

aunque en las pinturas leridanas habría que desestimar la segunda atribución ${ }^{119}$. Por otro lado, es lógico pensar que si estos personajes carecían de medios económicos para comer, mucho más para poder adquirir ropas. De hecho, en muchas ocasiones, las donaciones que se hacían a la Almoina para los pobres consistían, además de la porción alimenticia, en ropas o telas para confeccionar vestimentas. Recordemos en este sentido la inscripción de la lápida mortuoria del arcediano de Tarantona y canónigo y prepósito de Valencia Raymundo de Montañana -1309-, en la que se nos relata cómo, además de las instituciones de pobres en la Almoina de Lleida y en la de Valencia, fundó también cuatro piezas de paño y cien alnas de estopa de lino para ser repartidas entre los pobres con el objeto de recomponer sus ropas de vestido ${ }^{120}$. En conexión con la ya mencionada liturgia funeraria y sus implicaciones caritativas, también se les daba ropa cuando se disponía que un número determinado de pobres acompañase al difunto el día del entierro: Item vull e man que lo dia de la mia sepultura sien donades dotze gramalles de drap blau ab sos capirons a dotze pobres e un solitum a cascun pobre, e aquells dotze pobres haien a anar ab ses gramalles e capirons vestits davant lo meu cors quant ser liurat a ecclesiastica sepultura ab sengles siris en les mans si e segons que en semblants es acostumat ${ }^{121}$.

Además de los pobres vergonzantes, en las pinturas ilerdenses aparecen otros personajes que, sin llegar a tener un status económico desahogado, tampoco pueden

${ }^{119}$ Al respecto véase A. GómEz GómeZ, “Cojos y miserables en la portada románica de Echano (Navarra)", Príncipe de Viana, LIV, núm. 198 (1993), pp. 9-27.

${ }^{120}$ P. SANAHUJA, Historia de la beneficencia..., op. cit., pp. 62-64. Vid. nota 30.

${ }^{121}$ Testamento del siglo XV, de Isabel de Soler (Arxiu del Palau, Lligall 361, c. 31, fol. 3r., publ. A. BORRÀS I FELIU, “L'ajuda als pobres en els testaments de Catalunya i València del segle XV", op. cit., p. 365). 
encabirse en los estratos sociales más bajos, propios de otros que hemos visto en el refectorio de Lleida. Me refiero a los estudiantes o aprendices de algún oficio. Entre éstos últimos aparecen en la documentación los niños cantores del Coro y Órgano de la Catedral, para los cuales en 1432, una Bula del Papa Eugenio IV autorizaba a que el cabildo de la Seu Vella les destinase catorce porciones claustrales ${ }^{122}$. En cuanto a los estudiantes, páginas atrás vimos cómo la Almoina admitía en su refectorio, al menos durante tres días a la semana, a los estudiantes del Estudi General ${ }^{123}$. Pero así como la documentación nos confirma su presencia, no presentan característica alguna destacable que pueda atribuirse a alguno de los personajes pintados y conservados de la Almoina que seguro tuvo alguna figuración de ellos.

Y ya para finalizar este recorrido por las pinturas de la Pia Almoina leridana, cabría tener presente la imagen del peregrino a Santiago de Compostela. En dichos frescos aparecen varias figuraciones de tal personaje, siempre fácilmente identificable por las conchas en el sombrero típico de romero, por el bordón y la bolsa. En total son seis las representaciones de este personaje cinco de ellas en el panel con número de inventario 2, y la restante en el correspondiente al número 3-, entre las que se encuentra también la de una mujer peregrina. Su presencia debió ser una constante en la vida cotidiana ilerdense. No es éste el lugar para hablar de peregrinaciones medievales, entre otras cosas porque ya otros hablaron de ello abundante y acertadamente, además de no ser ésta, tampoco, la finalidad del estudio. Simplemente recordar la importancia que tuvieron dichas romerías y, para el caso que aquí nos afecta, la que tenía como

\footnotetext{
${ }^{122}$ P. SANAHUJA, Historia de la beneficencia..., op. cit., pp. 181-182.

${ }^{123}$ Ibid., p. 175, nota 227
}

destino final Santiago de Compostela, ya que Lleida fue, durante la Edad Media, una ciudad muy vinculada a esta peregrinación, siendo uno de los enclaves fundamentales en los denominados caminos orientales de la Península ${ }^{124}$. Realizar la peregrinación hasta la tumba del Apóstol en la Edad Media, no exenta de muchas y graves contrariedades y peligros, tuvo una recompensa acorde a la dificultad de dicha prueba: la indulgencia plenaria. En páginas anteriores se comentó ya la importancia para aquellas gentes del perdón de los pecados cometidos y de la salvación del alma. Esto contribuyó a la generosidad que se manifiestó a lo largo de todo este período en otorgar limosnas y realizar obras caritativas también con los peregrinos, ya que eran vistos como personajes que asumían un gran sacrificio en su peregrinación hasta Compostela; razón por la cual, en ocasiones, se les dio cierto trato de favor respecto a otros pobres ${ }^{125}$. No en vano encontramos referencias bíblicas a tal personaje, exhortando a la limosna y a la caridad (Mt. 25, 34-40). Viendo todo esto no extraña la frecuencia con la que aparece en las representaciones artísticas medievales; recordemos los sepulcros leoneses ya vistos o bien su figuración en las Cantigas de Alfonso X. En la número CXLIV se narra un

\footnotetext{
${ }^{124}$ F. SINGUL, "El culto jacobeo en el Oriente peninsular hispánico: Cataluña, Valencia y Baleares", Santiago. La Esperanza. Colegio de Fonseca, Universidade de Santiago de Compostela, 22 de mayo-31 de octubre, 1999, Santiago de Compostela, 1999, pp. 115-124.

${ }^{125}$ Existían salvaguardas y privilegios especiales establecidos para los peregrinos que se reforzaban en los Años Santos (J. M. LACARRA, "Protección jurídica del peregrino", en L. VÁZQUEZ DE PARGA, J. M. LACARRA, y J. URÍA RÍU, Las peregrinaciones a Santiago de Compostela, 3 tomos, Madrid, 1948, cap. IV, pp. 255279, en especial p. 257). De igual manera y según citaba líneas arriba, en el Hospital de Santa María la Real de Burgos, no se permitía la entrada a mujeres con hijos o embarazadas, a excepción de las peregrinas (L. MARTínez GARcíA, La asistencia a los pobres en Burgos en la baja Edad Media... op. cit., p. 45)
} 
milagro de la Virgen, quien salvó a un hombre bondadoso de un toro. Las ilustraciones que se realizan para mostrar la bondad del personaje en cuestión y su fe por Santa María son a dicho hombre rezando ante la Virgen, y en la otra, a la puerta de su casa, dando una limosna a un peregrino. Creo que la imagen y el significado de la misma es bastante elocuente y clarificador al respecto ${ }^{126}$.

\section{LÍNEAS FINALES}

El peregrino, como representación de un grupo social susceptible de la caridad y la ayuda ajena, tuvo su cabida en las pinturas de la Pia Almoina leridana, de la misma manera que otros individuos que acabamos de ver. Esta circunstancia confiere a dichas pinturas un valor histórico y testimonial de una realidad muy cotidiana, que pocas representaciones figurativas medievales contienen. A esto habría que añadir el carácter práctico de los frescos y predominantemente funcional respecto al espacio en el que se encontraban en origen: la Pia Almoi$n a$, donde nuestras pinturas sirvieron como recordatorio y como indicador de las refacciones a celebrar, su fundador, el tipo de pobre agraciado, la porción que se le concedía y su localización en el espacio físico del refectorio. Por todo ello, las pinturas de la limosna ilerdense nos muestran la evolución pictórica de una misma iconografía, bien pensada, adecuada y definida al espacio arquitectónico y al desarrollo experimentado a través de los cambios producidos entre los siglos XIV y XVI, en la institución catedralicia a la que pertenecen las pinturas.

${ }^{126}$ Sobre la limosna y la caridad en la Edad Media véase C. LÓPEZ ALONSO, La pobreza en la España Medieval, op. cit. 

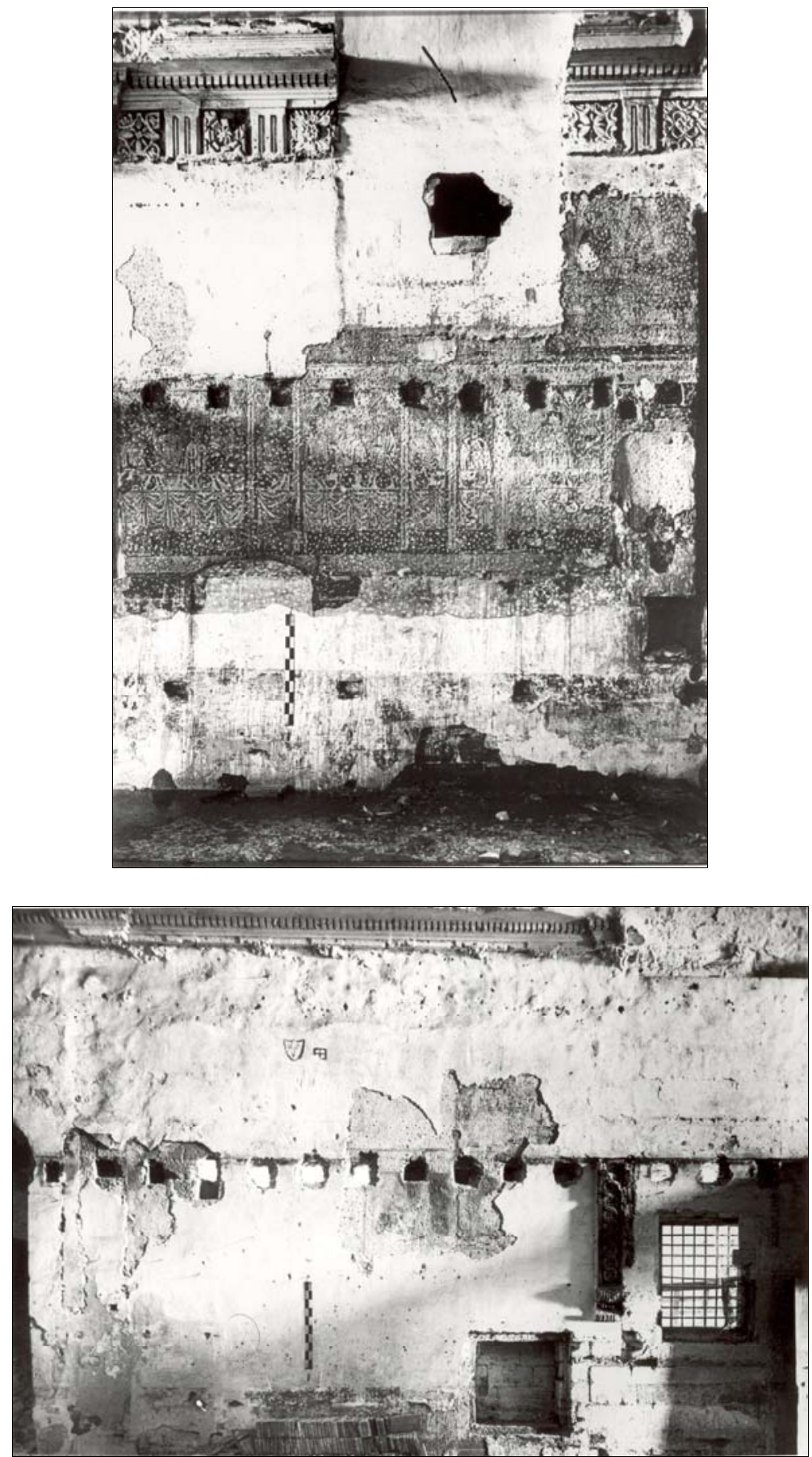

- Fig. 1. Muro norte del refectorio de la Almoina de Lleida. Fragmentos pictóricos correspondientes a los números de inventario 2 y 4; antes de ser arrancados del muro. (Institut Amatller $\mathrm{d}$ 'Art Hispànic) (arriba centro)

- Fig. 2. Muro sur del refectorio de la Almoina de Lleida. Fragmentos pictóricos correspondientes al número de inventario 1; antes de ser arrancados del muro. (Institut Amatller d'Art Hispànic) (abajo centro) 

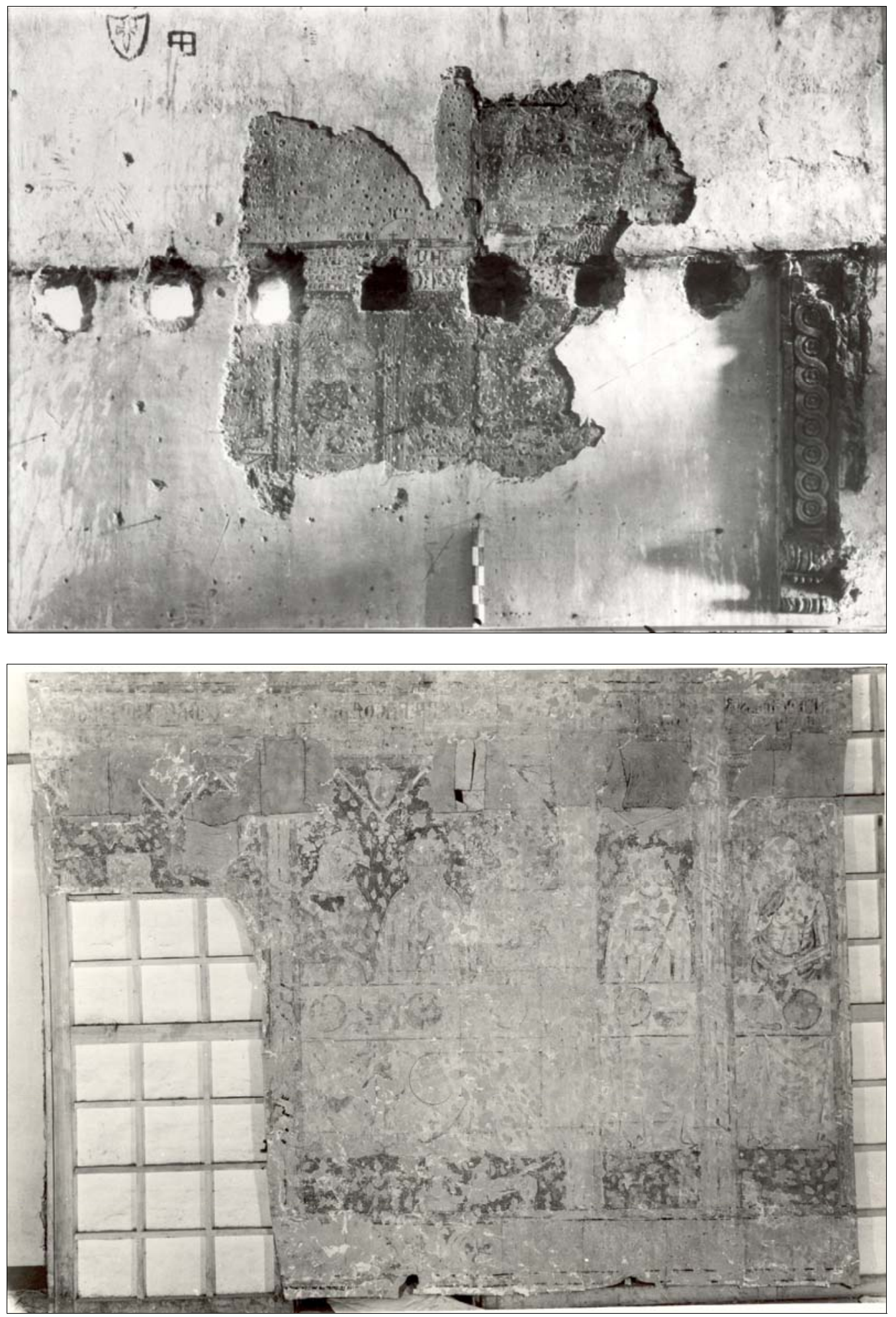

- Fig. 3. Detalle de la imagen anterior. (Institut Amatller d'Art Hispànic) (arriba centro)

- Fig. 4. Fragmento pictórico con $n^{0}$ de inventario 2, antes de la restauración. (Institut Amatller d'Art Hispànic) (abajo centro) 

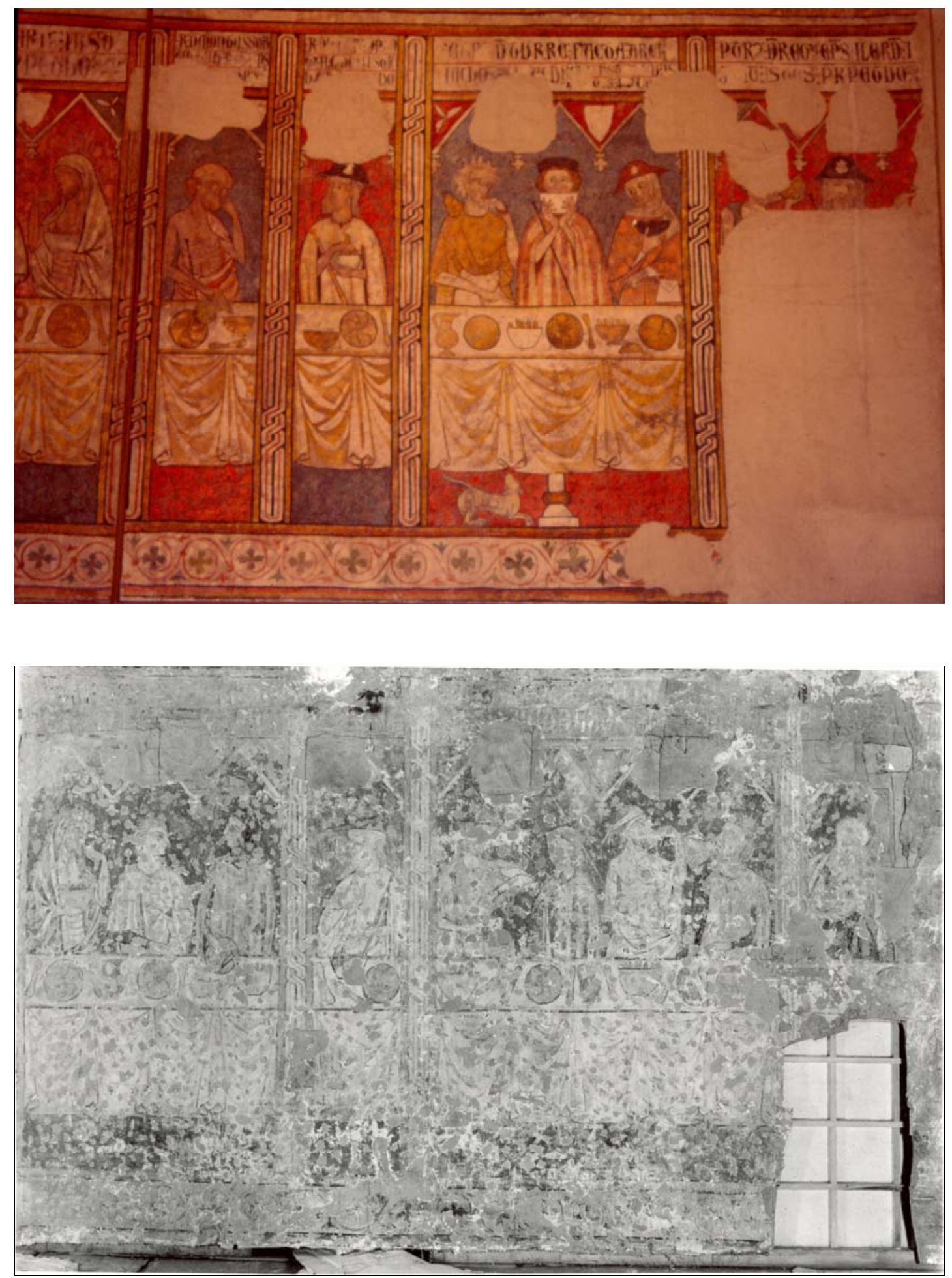

- Fig. 5. Fragmento pictórico con $\mathrm{n}^{\mathrm{o}}$ de inventario 2, tras la restauración (Museu Diocesà $i$ Comarcal de Lleida) (arriba centro)

- Fig. 6. Fragmento pictórico con $n^{0}$ de inventario 2, antes de la restauración. (Institut Amatller d'Art Hispànic) (abajo centro) 

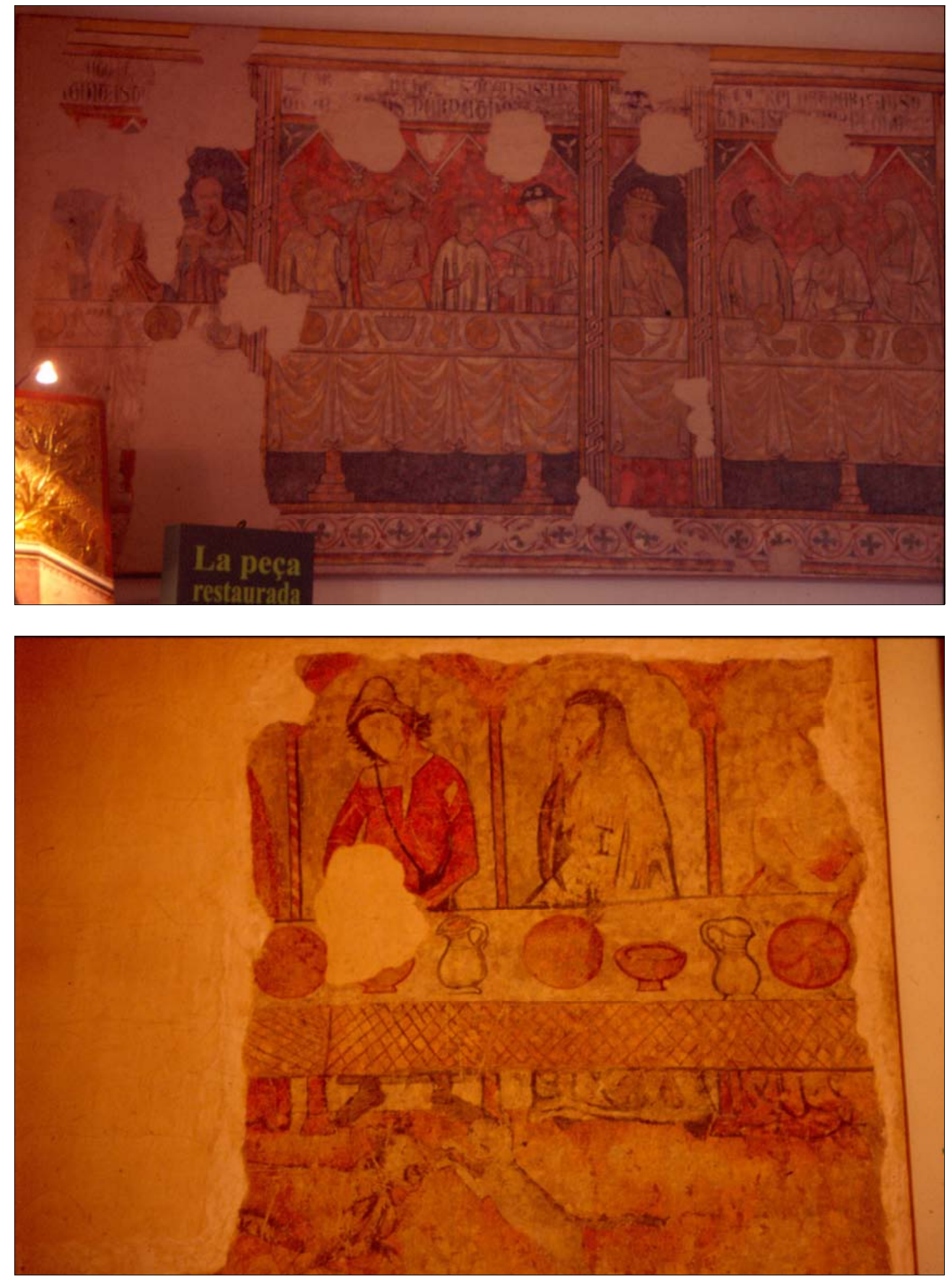

- Fig. 7. Fragmento pictórico con $\mathrm{n}^{\mathrm{o}}$ de inventario 2, tras la restauración (Museu Diocesà $i$ Comarcal de Lleida) (arriba centro)

- Fig. 8. Fragmento pictórico con n⿳o de inventario 4 (Museu Diocesà i Comarcal de Lleida) (abajo centro) 

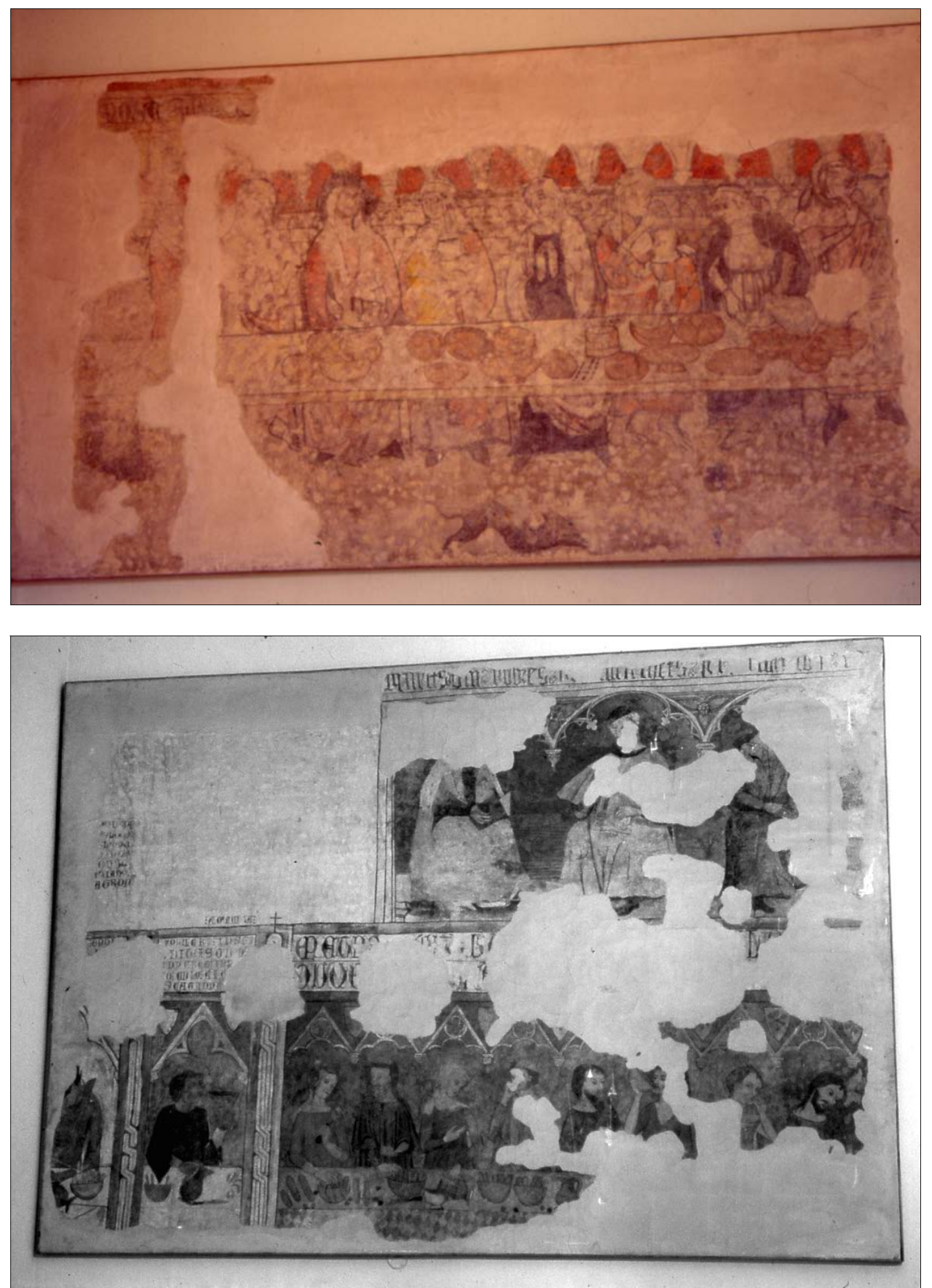

- Fig. 9. Fragmento pictórico con $n^{0}$ de inventario 6 (Museu Diocesà $i$ Comarcal de Lleida) (arriba centro)

- Fig. 10. Fragmento pictórico con no de inventario 1 (Museu Diocesà i Comarcal de Lleida) (abajo centro) 

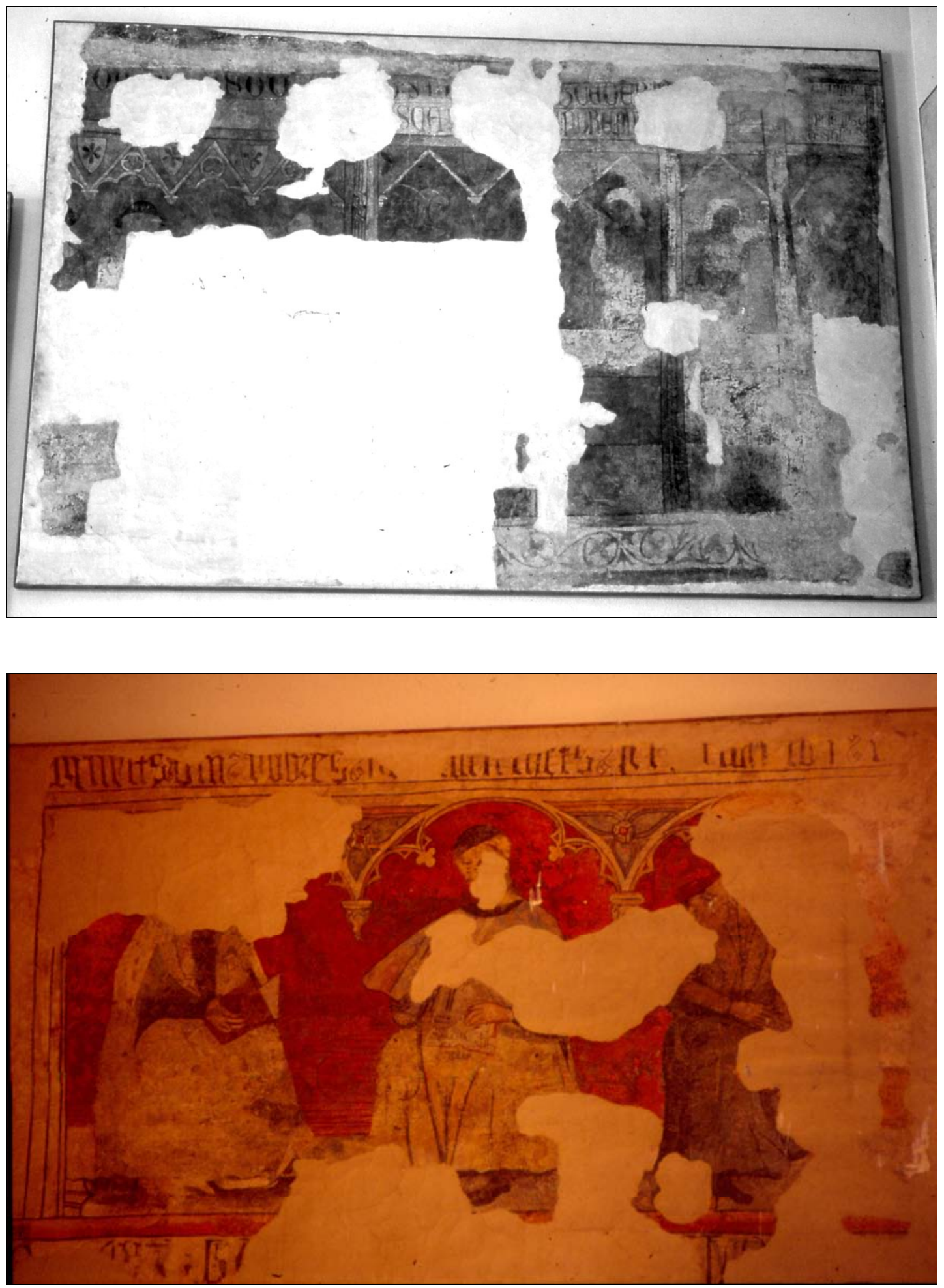

- Fig. 11. Fragmento pictórico con no de inventario 3 (Museu Diocesà i Comarcal de Lleida) (arriba centro)

- Fig. 12. Detalle de la zona superior del fragmento pictórico con $\mathrm{n}^{\mathrm{o}}$ de inventario 1 (Museu Diocesà i Comarcal de Lleida) (abajo centro) 

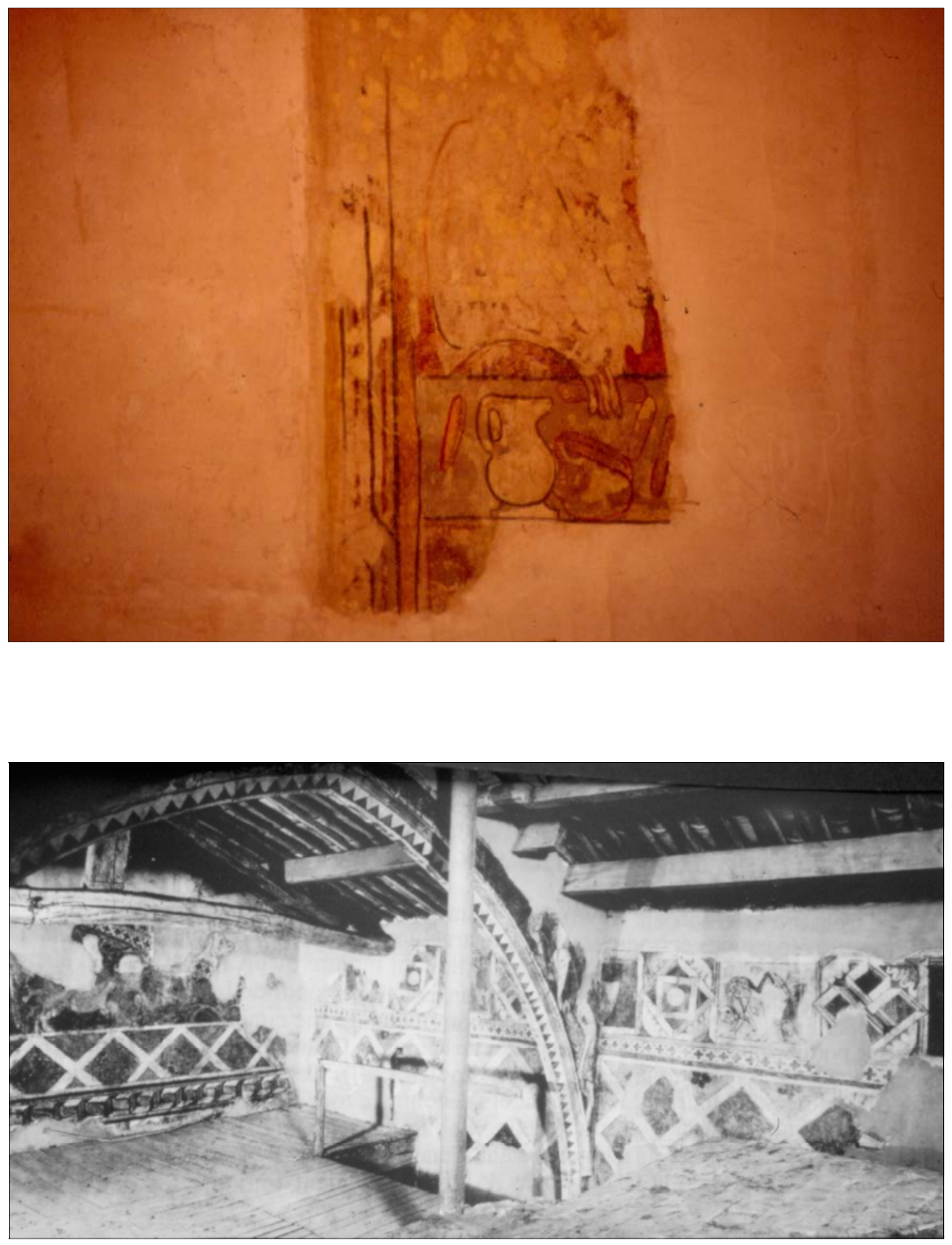

- Fig. 13. Frag. pictórico con $\mathrm{n}^{\mathrm{o}}$ de invent. 5 (Museu Diocesà $i$ Comarcal de Lleida) (arriba centro)

- Fig. 14. Refectorio de la Catedral de Viviers (abajo centro) 

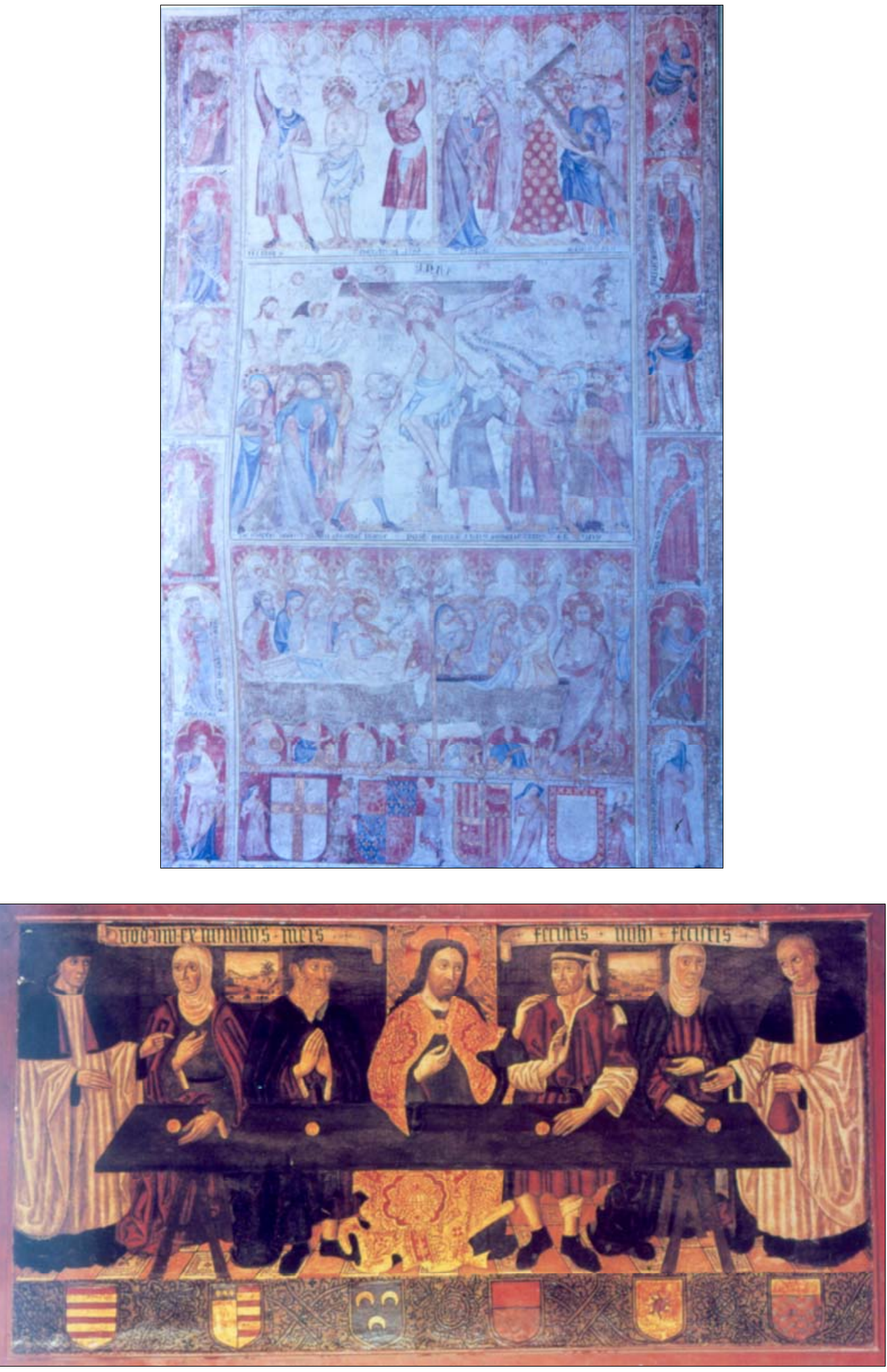

- Fig. 15. Pintura del refectorio de la Catedral de Pamplona (arriba centro)

- Fig. 16. Tabla de la Almoina de la Catedral de Palma de Mallorca (Museo. Catedralício) (abajo centro) 


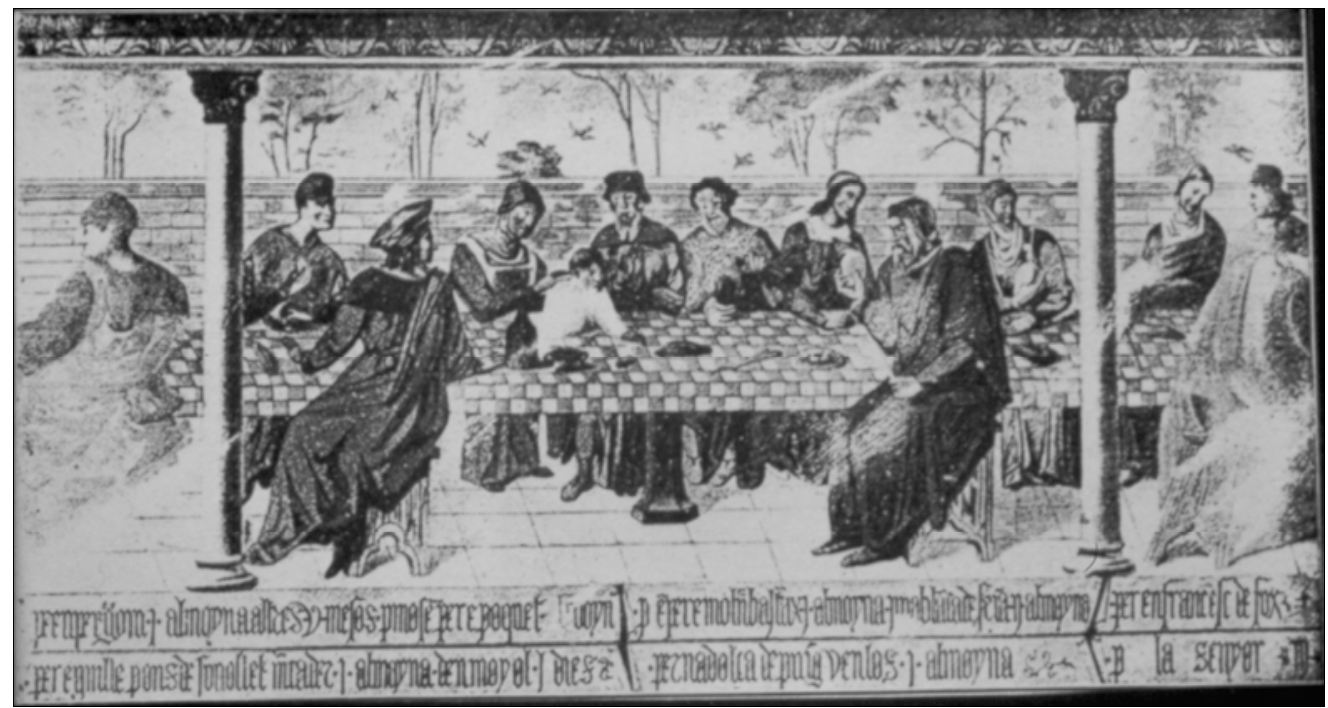

- Fig. 17. Cromolitografía de las pinturas de la Almoina de la Catedral de Barcelona, hoy desaparecidas. Foto F. Español (arriba centro) 